How Deep is the Annuity Market Participation Puzzle?

\author{
By \\ Joachim Inkmann \\ Paula Lopes \\ Alexander Michaelides \\ DISCUSSION PAPER NO 593 (UBS Paper 044) \\ UBS PENSIONS PROGRAMME AT THE LSE \\ DISCUSSION PAPER SERIES
}

July 2007

Joachim Inkmann is Assistant Professor in the Finance Department at Tilburg University. He is affiliated with the CentER Finance and Econometrics Groups at Tilburg University, with the Dutch Network for Studies on Pensions, Aging and Retirement, Netspar, and with the UBS Pensions Research Programme at LSE. His research and teaching interest focuses on the economics and finance of ageing. Paula Lopes obtained her Ph.D. in Economics at Boston University (Boston, USA) under the supervision of Professor Laurence Kotlikoff. In October 2002, she joined the Financial Markets Group, at the London School of Economics, as a Post-Doctoral Fellow in the UBS Pensions Research Programme. She has also carried out research within the European Union funded Research Training Network on Financing Retirement in Europe. Alex Michaelides is a Reader in Economics at the London School of Economics, a research affiliate of the Financial Markets Group at the LSE and a Research Affiliate of the Centre for Economic Policy Research. He holds a BA degree in economics from Harvard University and a MA and a PhD degree in economics from Princeton University. Any opinions expressed here are those of the authors and not necessarily those of the FMG. The research findings reported in this paper are the result of the independent research of the authors and do not necessarily reflect the views of the LSE. 


\title{
How Deep is the Annuity Market Participation Puzzle?*
}

\author{
Joachim Inkmann ${ }^{\dagger}$ \\ Tilburg University, CentER and Netspar
}

Paula Lopes ${ }^{\ddagger}$

London School of Economics and FMG

Alexander Michaelides ${ }^{\S}$

London School of Economics, CEPR and FMG

July 2007

\footnotetext{
*We thank the National Centre for Social Research, the University College London and the Institute for Fiscal Studies for making available the English Longitudinal Study of Ageing (ELSA) through the U.K. Data Archive at the University of Essex, and the latter for distributing the data. We appreciate stimulating discussions with Edmund Cannon, Joost Driessen, Theo Nijman and Ian Tonks. We also thank John Campbell, Katie Carman, Christian Gollier, Gur Huberman, David McCarthy and conference participants at Free University of Amsterdam, London School of Economics and Warwick Business School for helpful comments.

${ }^{\dagger}$ CentER and Netspar, Department of Finance, Tilburg University, P.O. Box 90153, 5000 LE Tilburg, The Netherlands. Email: j.inkmann@uvt.nl.

${ }^{\ddagger}$ FMG, London School of Economics, Houghton Street, London, WC2A 2AE, UK. Email: p.lopes@lse.ac.uk.

${ }^{\S}$ FMG and Department of Economics, London School of Economics, Houghton Street, London, WC2A 2AE, UK. Email: A.Michaelides@lse.ac.uk.
} 


\begin{abstract}
Using U.K. microeconomic data, we analyze the empirical determinants of voluntary annuity market demand. We find that annuity market participation increases with financial wealth, life expectancy and education and decreases with other pension income and a possible bequest motive for surviving spouses. We then show that these empirically-motivated determinants of annuity market participation have the same, quantitatively important, effects in a life-cycle model of annuity demand, saving and portfolio choice. Moreover, reasonable preference parameters predict annuity demand levels comparable to the data, thereby questioning the conventional wisdom that limited annuity market participation is a puzzle to be explained.
\end{abstract}

JEL Classification: E21, H00.

Key Words: Annuities, portfolio choice, bequest motive. 


\section{Introduction}

Why are annuities not voluntarily taken up by a larger number of retirees? In the individual consumption/savings-portfolio choice literature, a very important participation puzzle arises from the revealed preference of households not to voluntarily buy annuities at retirement, despite the strong theoretical reasons that point towards high demand for these products. Specifically, as early as 1965, Yaari demonstrated that risk aversion would be sufficient to induce a household to buy an actuarially fair annuity as protection against life expectancy risk. Yet, despite this early strong theoretical result, annuity demand remains very low in the data, ${ }^{1}$ what is known as the "annuity market participation puzzle".

It is important to understand why this puzzle arises from a theoretical perspective ${ }^{2}$ but there is also another, equally strong, empirical reason to explain the puzzle. Specifically, there has been a large shift in pension provision from defined benefit (DB) to defined contribution (DC) plans both in the U.S. and in the U.K.. DB plans offer not only a fixed monthly payment but also offer it for life, therefore providing a natural insurance for life expectancy risk. On the other hand, DC plans place the decision of how fast to decumulate during retirement in the hands of the individual. ${ }^{3}$ As a result, the issue of annuity provision could become a very important topic for the well-being of households making optimal financial plans after retirement, while the number of these households is forecast to increase both with the proliferation of DC plans and with population ageing. Understanding the reasons behind the observed low take-up of annuities during retirement can thus offer important insights in the role of policy and the design of state and employer-provided pension systems.

Understanding this puzzle has generated a large number of recent papers that have attempted an explanation. Potential explanations involve the lack of actuarially fair annu-

\footnotetext{
${ }^{1}$ More recently, Davidoff, Brown and Diamond (2005) show that complete annuitization is optimal in a more general setting than Yaari (1965) when markets are complete.

${ }^{2}$ Davidoff et. al. (2005) imply that an explanation from the psychology and economics literature might be needed.

${ }^{3}$ In the U.K. there is mandatory annuitization at age 75 of three quarters of the accumulated assets in a DC plan.
} 
ities, ${ }^{4}$ inflation risk, ${ }^{5}$ a strong bequest motive, ${ }^{6}$ habit formation in preferences, ${ }^{7}$ the presence of some annuitization through state social security and private DB plans, ${ }^{8}$ the presence of uncertain medical expenditures, ${ }^{9}$ non-actuarially fair annuity provision and minimum annuity size purchase requirements, ${ }^{10}$ rare events, ${ }^{11}$ and flexibility. ${ }^{12}$ Overall, however, the current conventional wisdom, as re-iterated by Davidoff, Brown and Diamond (2005), treats the limited voluntary annuity market participation as a puzzle that remains to be explained.

Nevertheless, despite this strongly-rooted conventional wisdom, very few studies have attempted to empirically analyze the determinants of voluntary annuity market participation at the household level. ${ }^{13}$ What are the characteristics of households that participate (or not) in this market? Understanding the factors affecting the participation decision can potentially help us quantify the magnitude of the puzzle relative to the predictions from different models

\footnotetext{
${ }^{4}$ See, for instance, Mitchell, Poterba, Warshawsky and Brown (1999) for the U.S. and Finkelstein and Poterba $(2002$, 2004) for U.K.. Nevertheless, Mitchell et. al. (1999) argue that annuity pricing is not sufficient to explain the low take-up and argue that the "money's worth of individual annuities" is actually quite good, therefore questioning this potential explanation of the puzzle.

${ }^{5}$ In the presence of substantial inflation risk the demand for nominal annuities might be quite low. Nevertheless, this explanation would imply a large demand for real annuities, yet the take-up for real annuities, where they exist, has also been low. Lopes (2006) also finds that the load factors for real annuities are high, thereby negating the value from having real annuities.

${ }^{6}$ The preference for leaving bequests may counteract the insurance benefits of annuities (Friedman and Warshawsky (1990), for example).

${ }^{7}$ Davidoff, Brown and Diamond (2005).

${ }^{8}$ Bernheim (1991), Brown et. al. (2001) and Dushi and Webb (2004).

${ }^{9}$ Sinclair and Smetters (2004), Turra and Mitchell (2004), and Webb (2005).

${ }^{10}$ See Lopes (2006).

${ }^{11}$ Lopes and Michaelides (2007) argue that the possibility of a "rare event" like the default of the annuity provider cannot by itself explain the puzzle since such a rare event would change behavior for high risk aversion coefficients but a high risk aversion simultaneously makes annuity demand stronger.

${ }^{12}$ Milevsky and Young (2002) argue that buying an annuity limits household flexibility to invest in the stock market. Ameriks et. al. (2007) find a significant aversion to ending up at a nursing home funded by the state; such "medicaid-aversion" may explain why households do not commit to the illiquid expenditure of buying an annuity.

${ }^{13}$ Recently, Brown and Poterba (2006) study variable (or equity-linked) annuities and focus on the impact of the household's marginal tax rate. Nevertheless, variable annuities only recently developed to a significant part of the total annuity market.
} 
of economic behavior. In this paper we first undertake such a task and investigate empirically the determinants of annuity market participation from the U.K. voluntary annuity market. ${ }^{14}$

Our empirical work provides an in depth analysis of what determines voluntary annuity market participation, and what affects the level of annuity demand conditional on participation. Our empirical results reconfirm and uncover certain stylized facts against which any theoretical model of the annuitization decision should be measured. We reconfirm that there appears to be a substantial voluntary annuity market participation puzzle since less than $6 \%$ of households participate in this market. Moreover, our multivariate analysis shows that annuity market participation increases with life expectancy, education and financial wealth. Pension income (or compulsory annuity income) crowds out annuity demand conditional on voluntary annuity market participation, while a possible bequest motive for surviving spouses is a hurdle for voluntary annuitization. In all regressions, we find that the annuitization behavior of stock market participants is better explained by a reduced form model than the behavior of stock market non-participants. We view these empirical findings as interesting in their own right since they increase our understanding of the determinants of annuity market participation and can provide a certain set of stylized facts that quantitative models can (or cannot) match.

In the second part of this paper we actually perform such a quantitative analysis. Specifically, we build a model of life-cycle saving, portfolio choice and annuity market participation subject to different (realistic) frictions and investigate whether reasonable assumptions about preferences and the economic environment can replicate the observed propensities to participate in the annuity market, and the level of annuities purchased conditional on participation. Given that the model is non-linear and is solved numerically, we perform a large number of comparative statics to understand the model's predictions in terms of policy functions.

\footnotetext{
${ }^{14}$ We focus on U.K. data (the English Longitudinal Study of Ageing (ELSA, see Marmot et al., 2006)) due to the the large array of annuity market products available to the consumer in this market. Brown (2001) has a similar research objective based on the U.S. equivalent of the U.K. data we use, but undertakes a different research strategy. Specifically, Brown (2001) focuses on first calculating the value of having access to an annuity market for each household (based on a life-cycle simulated model) and then relates this value to observable characteristics. Instead, we try to find the parameters of a simulated model that may shed light on annuity demand, after using the data to isolate the characteristics of actual annuity market participants.
} 
We then use the wealth distributions and median pension levels from the data as exogenous inputs to the model to generate the predicted demand for annuities at retirement for the different cases, further helping us understand the implications of the numerically-solved model.

We next use a method of simulated moments to estimate three preference parameters that can match as closely as possible three moments in the data: the annuity market participation rate, and, conditional on participation, the amount of annuities purchased and the share of wealth annuitized. We choose to perform this analysis separately for stockholders and nonstockholders both on account of our multivariate probit findings and due to the large impact stock market investment opportunities have on the annuity decision in the theoretical model. Specifically, households optimally choose not to buy an annuity if they realize they can have access to the stock market. The flexibility associated with investment in the stock market rather than locking in the fixed annuity payout seems to be an intuitive explanation for a number of households choosing not to buy an annuity and we therefore perform our structural estimation separately for the two groups of households (stockholders have access to the stock market and non-stockholders do not). ${ }^{15}$

We use our resulting estimates to address how deep is the annuity market participation puzzle. We find that the implications of the fully rational life-cycle model are consistent with the empirical findings for reasonable preference specifications. For both stockholders and non-stockholders, we need a mild bequest motive, a risk aversion of around 2 and an elasticity of intertemporal substitution of around 0.6, and we view these parameter estimates as reasonable estimates for preferences, consistent with the empirical evidence in, for

\footnotetext{
${ }^{15}$ We do not model the endogenous decision of whether to participate or not in the stock market. Gomes and Michaelides (2005) argue in a similar life-cycle model that households with low financial wealth can be kept out of the stock market with a small fixed cost. Given that in our data the households that do not participate in the stock market are much poorer in terms of financial wealth than stock market participants, we think that a small fixed cost will keep these households out of the stock market as well. We do not model this endogenous choice explicitly here to keep the model relatively simple. Nevertheless, we view this as a short-cut to having an explicit fixed cost (capturing anything from a monetary cost to a utility-cost coming from inertia or inability (through inadequate education) to assess information) that can generate an endogenous separation between participants and non-participants in the stock market.
} 
instance, Gourinchas and Parker (2002) and Vissing-Jorgensen (2002). Overall, comparing the predictions of the model with their empirical counterparts we find that reasonable calibrations can generate the low annuity demand observed in the data and that, therefore, the annuity market participation puzzle might not be as deep as previously thought.

The remainder of the paper is organized as follows. In Section 2, we present the multivariate probit (reduced form) results on the actual determinants of annuity market demand (defined as annuity market participation and the level of annuity demand conditional on participation). In Section 3 we perform a number of comparative statics exercises from a calibrated life-cycle model to understand what a quantitative model predicts about the annuity market. In Section 4 we estimate the structural parameters of this model and investigate the strength of the annuity market participation puzzle by comparing the moments in the data to the ones from the model. Section 5 concludes.

\section{Empirical Analysis}

\subsection{Dataset}

The empirical part of the paper is based on the English Longitudinal Study of Ageing (ELSA, see Marmot et al., 2006). ELSA is a biannual panel survey among those aged 50 and over (and their younger partners) living in private households in England in 2002. For most of the variables of interest we use data from the first wave of ELSA collected in 2002 and 2003. We restrict our analysis to households with either a retired single, or a couple with at least one retired person, since annuitization is likely to occur during retirement and we are interested in possible substitution effects between public and private pension income and annuities. ${ }^{16}$

We focus on voluntary annuitization, which is recorded in ELSA as a part of the "Income and Assets" module. After collecting information about the amounts of state pensions and private pensions from personal or employer pension schemes a household received during

\footnotetext{
${ }^{16}$ With this restriction, we exclude 2,206 non-retired households. We do not view this restriction as important for our analysis since we only observe 14 voluntary annuity contracts for these households in the first wave of ELSA.
} 
the year before the interview, the survey proceeds requesting information about the amount of received annuity income. The questionnaire gives a definition of annuity income, which should prevent any misinterpretation: "Annuity income is when you make a lump sum payment to a financial institution and in return they give you a regular income for the rest of your life." 17 Detailed descriptive statistics for the occurrence and magnitude of voluntary annuitization and for all other variables of interest will be given in the subsequent sections.

The "Income and Assets" module of ELSA is distributed to all financial units within a household. A financial unit is either a single person, or a couple if the latter declares to share their income and assets. If a couple treats their income and assets separately it will consist of two financial units. Financial units are to be distinguished from benefit units, which are either single persons or couples irrespectively of their agreement with respect to the sharing of financial means. Since we would like to use the annuity information on the least aggregated level, we prepare the data on a financial unit level and employ individual specific information (like age, gender, education, and health) of the person who filled in the "Income and Assets" module for our empirical analysis. This means that one household consisting of a couple which separates income and assets would enter our dataset with two observations while a couple with joint income and assets contributes one observation. Financial information for the household (like wealth, income) apart from annuities is collected on the household level.

The first wave of ELSA comprises 12,100 individuals. Our sample consists of 5,233 households. The reduction is explained by excluding households without a member in retirement (2,206 observations), excluding partners from couples who report joint income and assets (3,536 observations) and excluding observations with missing values for our variables of interest to be discussed below (1,125 observations).

It is not known when annuity recipients in the 2002/ 2003 wave of ELSA purchased their annuity. Optimally, we would like to observe household characteristics directly at the time of the annuity purchase to learn about the determinants of annuitization. We use the second wave of ELSA collected in 2004/ $2005^{18}$ to create this optimal scenario. Specifically, observations without annuity income in the first wave, but with reported annuity income in

\footnotetext{
${ }^{17}$ Note that there is no distinction between nominal, real and variable annuities in the data.

${ }^{18}$ The response rate of first wave participants was $82 \%$ in the second wave.
} 
the second, must have purchased their annuity in the time between the two surveys, that is roughly in 2003. By combining the second wave annuity information for these observations with the first wave household variables we achieve the desired match between the annuity and the household background immediately before the voluntary annuitization took place. Moreover, this procedure increases the number of observed annuities for our empirical analysis, which is helpful given the overall small fraction of annuity market participants (see below).

\subsection{Descriptive Statistics}

\subsubsection{Annuities}

Table 1 describes the annuity market participation decisions in our dataset, while at the same time presenting a split of this decision between households that participated or not in the stock market. We do this based on the idea that stock market participation might be correlated with the decision to participate in the annuity market since both decisions require a certain degree of financial sophistication. According to Table 1, only 5.9\% (309 observations) of the households in our sample received income from voluntary annuitization in either the first wave of ELSA (207 observations) or the second wave (102 observations). ${ }^{19}$ Compared to the stock of annuity market participants in wave one, the inflow of 102 new annuities between wave one and wave two appears large in size. This is not too surprising, however, given the U.K. media attention on pensions during 2003 and 2004. Nevertheless, 309 voluntary annuity contracts among 5,233 households remains a very small number. This is

\footnotetext{
${ }^{19}$ In December 2002 the Government appointed the Pensions Commission with the task to review the adequacy of private retirement savings in the U.K.. In June 2003 the Commission published a working plan and in October 2004 a first report (see Pensions Commission, 2004). Throughout this time, the Commission, the Commission's Chairman and pensions were prominently featured in the U.K. media, which might have raised public awareness towards retirement savings and potentially resulted in an increase in voluntary annuitization. A second factor contributing to an increase in voluntary annuity market participation after 2002 could be the default of the Defined Benefit pension scheme of Allied Steel and Wire in July 2002, which again was prominently featured in U.K. media, and might have induced some people to diversify their pension income portfolio.
} 
exactly what is generally referred to as the annuity market participation puzzle. Moreover, the puzzle seems to exist even in the U.K. which is generally accepted to have the most mature annuity market in the world (see Finkelstein and Poterba, 2002, 2004). ${ }^{20}$

Table 1 also indicates that there might be an interesting correlation between the decision to participate in the stock market and the decision to purchase an annuity. Stock market participation $^{21}$ is around $42.5 \%$ of the total sample but the percentage of stock market participants purchasing an annuity $(9.6 \%)$ is three times the percentage of stock market nonparticipants $(3.2 \%)$. The difference is statistically highly significant with a t-test statistic of 9.1. Equivalently, Table 1 shows that more than two thirds (213 out of 309) of all annuity market participants also participate in the stock market. Thus, there seems to be some connection between the decision to participate in the two markets and we will investigate this further in both the empirical and theoretical analysis that follows.

Table 2 presents annuity demand statistics conditional on participating in the voluntary annuity market. Specifically, the table reports mean and median annual annuity income statistics and splits the sample across the stock market participation decision as well. Conditional on having an annuity, the mean annual annuity income is about 3,000 GBP, but this is dominated by a number of very large annuities as the median of about 1,000 GBP shows. Stock market participants tend to demand higher annuities as indicated by a mean (median) annual annuity income of about 3,650 (1,200) GBP. These descriptive statistics give us an idea about the level of annuity demand that a structural model should be generating to match the empirical evidence.

The rest of this section will investigate what household characteristics determine voluntary annuity market participation and, conditional on participation, what affects the magnitude of voluntary annuity demand. We focus on three groups of variables that might affect these decisions: wealth and income, health and life expectancy and socio-economic

\footnotetext{
${ }^{20}$ Banks and Emmerson (1999) use the family resources survey and report similar statistics for voluntary annuity market participation.

${ }^{21}$ We define a stock market participant as a household that has stocks in an individual savings account (ISA), or a personal equity plan (PEP), or indirect stock holdings in an investment trust, or direct holdings of stocks.
} 
background variables like education, marital status and the number of children.

\subsubsection{Wealth and Income}

Table 2 reports mean and median statistics for a number of financial variables that may be important determinants of voluntary annuity market participation and annuity demand conditional on participation. We focus on variables that have been shown to be important in the limited stock market participation literature (see Campbell (2006) for a recent review) due, in part, to the potential link between participating in the two markets. Specifically, we focus on financial wealth, the annual amount of total pensions (excluding any voluntary annuity), and the decomposition of the latter into public and private (personal or employer) pensions.

To be informative about annuity take-up decisions, financial wealth should be measured before annuitization takes place. As explained before, this is readily achieved for the new annuities observed in the second wave of ELSA where the first wave contains the appropriate wealth before the annuity purchase. For annuities already observed in the first wave we approximate the cost of annuitization by multiplying the annual annuity income with the annuity factor and add this to the household's financial wealth. We use an annuity factor of $13 .^{22}$

Table 2 reports the mean financial wealth ${ }^{23}$ of annuitants to be about 135,000 GBP and thus around 85,000 GBP larger than the wealth of non-annuitants. The corresponding median values are 65,000 GBP and 14,200 GBP, respectively. This already suggests that voluntary annuity market participation mostly occurs among the relatively rich households. More detailed evidence is displayed in Figure 1. The figure shows average voluntary annuity

\footnotetext{
${ }^{22}$ The annuity factor was calculated using the Financial Services Authority comparative tables. These tables show the monthly payments offered by the main annuity providers under the open market option. The monthly payments correspond to a purchase price of 100,000 GBP of a single life annuity, with no guarantee, for a 65 -year old male. We use the average monthly payment across providers to calculate the corresponding annuity factor.

${ }^{23}$ We do not use housing wealth in our multivariate analysis because we view the relatively higher liquidity in financial wealth (with respect to housing) as a more relevant criterion for the household decision to annuitize or not.
} 
market participation across the $2.5 \%, 10 \%, 25 \%, 50 \%, 75 \%, 90 \%$ and $97.5 \%$ percentiles of the wealth distribution. While average participation is less than $1 \%$ among the 262 households in the bottom $5 \%$ of the wealth distribution $(2.5 \%$ wealth quantile $=100 \mathrm{GBP})$, it increases steeply to almost $20 \%$ among the 262 households in the top $5 \%$ of the wealth distribution $(97.5 \%$ wealth quantile $=348,800 \mathrm{GBP})$. Among the $30 \%$ households around median financial wealth, slightly more than $4 \%$ participate in the voluntary annuity market. Given that the $10 \%$ and $25 \%$ quantiles of the wealth distribution are $700 \mathrm{GBP}$ and 3,300 GBP, respectively, it seems fair to say that households in the lower third of the wealth distribution are generally constrained by insufficient financial wealth to participate in the voluntary annuity market.

Figure 1 also decomposes the sample across wealth quantiles into stock market nonparticipants and participants. While stock market participants are still slightly outnumbered around the median wealth by non-participants, almost all households around the $75 \%$, 90\% and $97.5 \%$ percentiles of the wealth distribution are stock market participants. The mean (median) wealth investors who participate in both markets is $174,000(100,000)$ GBP according to Table 2, which is considerably higher than the mean (median) wealth of the average annuity market participants and places the former among the very rich. In terms of broad portfolio allocations, the average (median) allocation of financial wealth to stocks is $38 \%(32 \%)$ for stock market participants and 35\% (28\%) for participants in both the stock market and the voluntary annuity market.

Apart from insufficient wealth, one obvious explanation for non-participation in the voluntary annuity market is the existence of other sources of pension income. The institutional details of the U.K. pension system have been described elsewhere (for example, Blundell et al., 2002, and Blake, 2003) and we only summarize its main features. The main part of the public pension system in the U.K. is the flat Basic State Pension (BSP) which is linked to the price level. ${ }^{24}$ In 1978 a second tier of public pensions was introduced in the U.K., the State Earnings Related Pension Scheme (SERPS, which has been replaced with the State Second Pension (S2P) in April 2002). Employees earning more than the so-called lower earnings limit (75 GBP per week in 2002) automatically participate in the second tier of

\footnotetext{
${ }^{24}$ The pension from this source was around 80 GBP per week at the time of the first wave of ELSA interviews in 2002 .
} 
the public pension system. ${ }^{25}$ Both occupational and personal private sector pensions in the U.K. are subject to compulsory annuitization laws. At least a part of the lump sum payment received from these schemes at retirement age has to be used to purchase an annuity within a certain time from retirement. These compulsory annuities are to be distinguished from the voluntary annuities purchased from non-pension wealth, which are the topic of this paper. Finkelstein and Poterba (2002) indicate that the compulsory annuity market in the U.K. is much larger than the voluntary annuity market: in 1998 the former had a size of 5.4 billion GBP while the latter equaled 0.8 billion GBP.

Both the earnings-related tier of the public pension system and the compulsory annuity market embedded in the private pension system might be seen as close substitutes for the voluntary annuity market under consideration here. For private savings in general, Attanasio and Rohwedder (2003) indeed find that the earnings-related tier of the U.K. public pension system serves as a perfect substitute. Table 2 shows mean and median annual pensions for the whole sample and different sub-samples of annuity and stock market participants. While the level of public pensions hardly changes over sub-samples, there is considerable variation in private pensions (that is, pensions from occupational or personal pension schemes). Annuity market participants receive higher private pensions (mean about 7,250 GBP; median 3,200 GBP) than annuity market non-participants (mean about 4,350 GBP; median 1,350 GBP). The highest average and median private pensions are observed in the sub-sample of individuals participating both in the voluntary annuity market and the stock market. At

\footnotetext{
${ }^{25}$ Originally, SERPS was supposed to pay a pension in the magnitude of $25 \%$ of the average of an individual's best 20 years of earnings. However, when SERPS was introduced, employees already participating in an occupational DB pension scheme could opt out of SERPS as long as their private pension scheme provided a pension, which was at least as high as SERPS. Employees who opted out of SERPS paid fewer National Insurance contributions as a consequence. Blundell et al. (2002) point out that more than half of all employees and more than two-thirds of all male employees exercised this option when SERPS was introduced. These employees (and those who opted out at a later time) would receive a private pension instead of SERPS during retirement. The possibility to opt out of the earnings-related tier of the public pension system has been extended from DB to occupational DC pension schemes and to personal private pension schemes in later years provided that these schemes fulfill certain conditions, which ensure that individuals are not worse-off if they opt out.
} 
this stage, it is too early to connect these results with the (non-) existence of a possible crowding out of voluntary annuities by private pension arrangements. The described pattern of observed high private pensions for voluntary annuity market participants could be simply attributed to their higher financial wealth.

Figure 2 decomposes the sources of pension income over different quantiles of the wealth distribution. Quite strikingly, the level of public pensions resembles a flat pension (of roughly 4,500 GBP per year) despite the earnings-related tier of the system (from 1978 onwards). There are two explanations for this: first, the average sample member already was 45 years old at the time SERPS was introduced in the U.K.. Thus, roughly half of the working life already has been spent in the absence of an earnings-related tier. Second, many of these employees already were members of an occupational DB scheme at the time SERPS was introduced and decided to opt out. Evidence for this is given by Figure 2, which shows that private sector pensions (the compulsory annuity market) increase steeply over the wealth distribution. Compared to the level of public and private pensions, voluntary annuities are small in magnitude. Figure 2 shows that sizable average annuities only exist around the $75 \%, 90 \%$ and $97.5 \%$ wealth percentiles.

Summarizing, we find that both pensions (compulsory annuities) and voluntary annuities increase on average with financial wealth. We leave it to the subsequent multivariate regression analysis to determine whether pensions crowd out voluntary annuities for a given level of wealth.

\subsubsection{Health and Life Expectancy}

Apart from wealth and existing pensions, an individual's health condition and her life expectancy (as a shortcut for the whole distribution of the random variable "time of death") should also affect the decision to annuitize since annuities hedge longevity risk. These products are in fact priced to reflect the average life expectancy of annuity market participants and condition on age and gender. If an individual has private information suggesting that she is unlikely to reach the age of an average annuity market participant, she will not buy an annuity simply because the product is overpriced for her. Finkelstein and Poterba (2002, 
2004) indeed find evidence for adverse selection in the U.K.'s annuity market: participants in the voluntary annuity market tend to live longer than non-participants. More generally, Rosen and $\mathrm{Wu}$ (2004) find evidence from the Health and Retirement Survey that health status affects portfolio choice and stock market participation. Since annuities are a form of financial product that is even more explicitly linked to health status, we expect that health can be a strong predictor of participation in the annuity market.

Despite the higher life expectancy of women, they make up only $42 \%$ of the sample in the voluntary annuity market, even though $53 \%$ of all sample members is female (Table 3 ). Thus, gender as an objective measure of life expectancy does not seem to explain annuity market participation. Nevertheless, ELSA allows us to analyze subjective probabilities of survival as an alternative determinant of the annuitization decision. ${ }^{26}$ The questionnaire asks individuals of age less or equal than $65(69,74,79,84$ and 89 , which is the maximum age in our sample) "What are the chances that you will live to be 75 (80, 85, 90, 95 and 100, respectively) or more?" and gives a range from $0 \ldots 100$ for possible answers. We interpret answers as probabilities and confront the subjective survival probabilities with gender and age specific "objective" probabilities of survival to the respective age limit, which we compute from the life tables published by the Government Actuary's Department (GAD, 2006) from data between 2002-2004. Table 3 shows that average values for subjective and objective GAD probabilities are very close to each other and do not differ by more than one percentage point for the whole sample and the two sub-samples of voluntary annuity market (non-) participants. This confirms prior evidence by Hurd and McGarry $(1995,2002)$ for the U.S. that subjective probabilities tend to aggregate well to population probabilities. However, we find that younger survey participants in ELSA underestimate population probabilities, ${ }^{27}$ while older survey participants tend to overestimate these probabilities. ${ }^{28}$ Specifically, individuals

\footnotetext{
${ }^{26}$ Prior research by Hurd and McGarry $(1995,2002)$ shows that reported subjective probabilities in the Health and Retirement Study (HRS) aggregate to population probabilities and are correlated with an individual's observable characteristics like health in the expected way. The authors recommend using these subjective probabilities in models of inter-temporal decision-making.

${ }^{27}$ This was already observed by Banks and Blundell (2005) for the same data.

${ }^{28}$ This is an example of the probability weighting function of Prelec (1998): individuals tend to overweight low probabilities and to underweight high probabilities.
} 
aged below the average sample age of 69 tend to underestimate the more the older they are reaching a maximum of two percentage points in the age group 65-69, while individuals above the average sample age tend to overestimate with a maximum of two percentage points in the age group 80-84. This indicates that the timing of the annuitization decision might affect its outcome.

We see from Table 3 that annuity market participants report a survival probability higher than non-participants by five percentage points. The difference in objective GAD survival probabilities is three percentage points and thus slightly smaller. These results are in line with the Finkelstein and Poterba $(2002,2004)$ self-selection findings for the voluntary annuity market in the U.K.. Table 3 also shows that annuity market participants slightly overestimate survival probabilities relative to the GAD probabilities by one percentage point, while nonparticipants tend to to underestimate survival probabilities by one percentage point which confirms the adverse selection hypothesis.

Finally, we try to shed some light on what determines the difference between (selfreported) subjective and (GAD) objective survival probabilities. The obvious candidate for any discrepancy between the two probabilities is private information about the individual's health condition. Figure 3 reports average differences in survival probabilities by the individual's self-reported health condition ranging from bad health to good health. ${ }^{29}$ Table 3 shows that $62 \%$ of the sample members consider their health condition as medium according to our definition, while $19 \%$ either report bad or good health condition. There is a clear shift from the bad health to the good health category for annuity market participants as Table 3 shows. The pattern in Figure 3 clearly indicates that health condition drives differences between subjective and objective survival probabilities. Those reporting a medium health condition estimate the population probability on average without bias, those reporting a bad health condition underestimate by almost two percentage points and those reporting a good health condition overestimate by more than one percentage point. This confirms similar results by Hurd and McGarry $(1995,2002)$ for the U.S. and gives us confidence to use subjective survival probabilities in the subsequent regression analysis.

\footnotetext{
${ }^{29}$ Bad health refers to values 4 and 5 on a 5 points scale decreasing with health condition while good health corresponds to value 1 .
} 


\subsubsection{Socio-Economic Background}

The final group of variables possibly affecting annuity market participation decisions is household composition and education. Education might matter since annuity products require a basic level of financial literacy. ${ }^{30}$ A household not understanding the purpose and structure of annuity products will not demand annuities. We differentiate between three education levels: low, medium and high. ${ }^{31}$ Table 3 shows that annuity market participants are on average much better educated than non-participants. While $61 \%$ of the non-participants are in the lowest education group, only one-third of the annuity holders are in the low education category. For the high education level, the order changes: only $10 \%$ of non-participants have a higher education degree compared to $25 \%$ of voluntary annuity market participants.

We study the household composition with bequests in mind, which might be a barrier for voluntary irreversible annuitization. We view bequests as the intention to leave behind financial wealth for the spouse and/or the children. Table 3 does not indicate that marital status and the number of children vary between the two sub-samples of participants and non-participants. $57 \%$ of participants are married, compared to $56 \%$ of non-participants. The average number of children is two in both cases.

However, the variables in this sub-section (education, marital status, and the number of children) are correlated with wealth and income. Only the subsequent multivariate econometric analysis may identify the impact of each of the variables on household annuitization decision by controlling for the remaining variables at the same time.

\subsection{Econometric Analysis}

We investigate the household's decision to participate in the voluntary annuity market and the demand of annual annuities conditional on participation in a multivariate regression setup.

\footnotetext{
${ }^{30}$ In addition, Lusardi and Mitchell (2006) provide evidence that individuals planning for retirement generally exhibit a higher degree of financial literacy than non-planning individuals.

${ }^{31}$ Low $=$ NVQ1, CSE or equivalent, medium $=$ NVQ2/3, GCE A/O level or higher education without degree, high $=$ NVQ4 $/ 5$.
} 


\subsubsection{Annuity Market Participation}

Table 4 displays the results of a Maximum Likelihood estimation of a Probit model for the household's decision to participate in the voluntary annuity market or not. The annuity market participation variable is comprised of existing annuities observed in the first wave of ELSA and new annuities observed in the second wave of ELSA. To see if this aggregation of existing and new annuities is meaningful, we also estimated the Probit model for existing and new annuities only. Since the results confirmed the findings of Table 4 we do not report these regressions here.

The previous section revealed systematic differences (for example, with respect to wealth and existing pensions) between the two subsamples of stock market participants and nonparticipants which are likely to be reflected in the annuitization decision. For this reason, we present separately the estimation results for stock market non-participants (Table 4, Panel A) from the results for participants (Table 4, Panel B). We use as explanatory variables the following: wealth, income, household composition, age, health and life expectancy of the household. In presenting the results, since the estimated coefficient in the probit model only shows the qualitative impact of an explanatory variable, we also compute marginal effects to assess the quantitative impact. We do this for a baseline observation that is defined as a 65 years old single male, without children, medium education, an average reported survival probability, average pension income and financial wealth. ${ }^{32}$

Confirming the earlier descriptive statistics in Table 2, financial wealth ${ }^{33}$ is shown to be one of the most important predictors of annuity market participation, ${ }^{34}$ for both nonstockholders and stockholders. A $1 \%$ increase in financial wealth significantly increases the annuity market participation probabilities of non-stockholders (stockholders) by 2.3 (3.6) percentage points. On the other hand, pension income (which is the aggregate of public and private sector pensions depicted in Figure 2) turns out to be statistically insignificant for

\footnotetext{
${ }^{32}$ Asymptotic t-values are computed for the marginal effects by means of the delta method.

${ }^{33}$ Wealth and income information is used in logs. In this way, the marginal effect can be interpreted like an elasticity.

${ }^{34}$ For all financial variables, we tested for possible nonlinearities by including a squared term. This term always turned out insignificant.
} 
both stockholders and non-stockholders.

Turning to health and life expectancy, we find that the health indicators turn out insignificant once we control for the subjective survival probabilities. Having seen the close correlation between these variables in Figure 3, this is not surprising. Correspondingly, we only include the survival probabilities in the regression, since these are a direct measure of the longevity risk targeted by annuities. This variable affects differently the annuitization decision of non-stockholders and stockholders. While statistically and economically insignificant for non-stockholders, the variable turns out to be the quantitatively most important predictor of the annuitization decision for stockholders. A one percentage point increase in the survival probability significantly increases the annuity participation probability by 4.7 percentage points as can be seen from Table 4.

Married financial units are significantly less likely to purchase an annuity. The marginal effects suggest that changing the marital status of the baseline household from single to married would significantly decrease the probability to participate in the voluntary annuity market by almost four percentage points. This turns out to be the quantitatively most important impact on the annuitization decision for non-stockholders. On the contrary, the number of children (or the presence of children or grandchildren in alternative unreported specifications) does not have a significant effect. This could mean that any bequest motive focuses on the spouse and not on the children. Alternatively, the large impact of marital status could be interpreted as intra-household hedging of longevity risk, instead of relying on the annuity market. However, the explanatory financial wealth and pension income variables are measured on the household level and already comprise the wealth and income of the spouse. Therefore, the bequest motive appears to be the more suitable explanation of the importance of the marital status variable.

With regards to other variables, age enters the regressions with a linear and a square term and both terms are insignificant for non-stockholders but highly significant for stockholders. The coefficients for the latter group imply that annuity market participation increases up to an age of 73 years and decreases afterwards. ${ }^{35}$ Women, despite their life expectancy

\footnotetext{
${ }^{35}$ For a real option model of delayed annuitization, Milevsky and Young (2002) find that 73 is the optimal annuitization age for a 60 years old male who estimates his life expectancy without bias.
} 
advantage in the population, are significantly less likely to be voluntary annuity market participants. Changing the gender of the baseline household from male to female significantly reduces the participation probability by two percentage points for both non-stockholders and stockholders.

We include dummies for low and high education levels as a measure of financial literacy. The low education dummy shows up significantly negative for both non-stockholders and stockholders. The high education dummy has the expected positive sign but turns out to be insignificant. Changing the education level of the baseline household from medium to low decreases the annuity market participation probability by roughly 2.6 percentage points. This is a quantitatively large effect and underscores the importance of financial literacy.

Overall, we find more statistically significant predictors of voluntary annuitization for stockholders than for non-stockholders. This is remarkable since the size of the stockholders subsample $(2,220$ households) is much smaller than the size of the non-stockholders subsample (3,013 households). However, since we observe more stockholders participating in the voluntary annuity market than non-stockholders, our model does a relatively better job in explaining the behavior of the former.

\subsubsection{Conditional Annuity Demand}

We estimate a linear regression model for annuity demand measured in terms of log annual annuity income on the sub-samples of annuity market participants. Results are again given in Table 4, Panel A, for non-stockholders and Panel B for stockholders. We estimate by OLS and report asymptotic t-values using White's (1980) heteroskedasticity-consistent estimator of the asymptotic standard errors.

All non-financial background variables appear insignificant in the conditional annuity demand regressions. These variables affect participation but do not influence demand conditional on participation. The financial variables, however, remain significant predictors of annuity demand. A $1 \%$ increase in financial wealth increases the voluntary annuity demand of non-stockholders (stockholders) by $0.33 \%$ (0.63\%). While pensions do not significantly affect the annuity demand of non-stockholders, they have a negatively significant impact for 
stockholders. A $1 \%$ increase in compulsory annuities crowds out the demand for voluntary annuities by $0.22 \%$.

Again we find more significant predictors for stockholders than for non-stockholders. This is also reflected by a larger $R^{2}$ in the annuity demand regressions for stockholders $(22.5 \%)$ compared to non-stockholders (13.6\%).

\subsection{Summary}

We provide an in depth empirical analysis of the voluntary annuity market participation decision and the annuity demand conditional on participation. We summarize here our most important empirical findings against which any theoretical model of the annuitization (participation and demand) decision should be measured. We reconfirm that there appears to be a substantial voluntary annuity market participation puzzle since less than $6 \%$ of households participate in this market. Moreover, annuity market participation increases with financial wealth, life expectancy and education. Pension income (or compulsory annuity income) crowds out annuity demand conditional on voluntary annuity market participation, while a possible bequest motive for surviving spouses is a hurdle for voluntary annuitization. In all regressions, we find that the annuitization behavior of stock market participants is better explained by a reduced form model than the behavior of stock market non-participants.

\section{Understanding the Implications of a Life-cycle Model}

In the next two sections we investigate the implications of a life-cycle model of annuity demand and portfolio choice and assess the model's consistency with the empirical findings in the previous section.

\subsection{The Model}

\subsubsection{Available Annuity Contracts}

We study nominal annuity contracts but for simplicity we assume zero inflation. One main component of the analysis involves calculating the expected present discounted value (EPDV) 
of the annuity, since the insurance company uses this value to calculate the price of the product. The EPDV will depend on the annual annuity payment, the survival probabilities and the term structure of interest rates at the time of retirement. For instance, if at retirement age the annualized interest rate on a bond with maturity $t$ is $r_{t, 1}, p_{t}$ denotes the probability that the household is alive at date $t$, conditional on being alive at date $t-1\left(p_{1} \equiv 1\right)$ and the household purchases an annuity that makes an annual payment of $A$, the expected present discounted value (EPDV) of the annuity payouts is given by:

$$
E P D V=\sum_{j=1}^{T} \frac{A \prod_{k=1}^{j} p_{k}}{\left(1+r_{j, 1}\right)^{j}}
$$

We use this EPDV to determine the cost of buying an annuity at retirement by multiplying the EPDV with one plus a load factor $(P)$ which is greater than or equal to zero, obtaining a measure of the "money's worth" of the annuity. If the load factor is zero, then the annuity contract is actuarially fair and the "money's worth" equals one. ${ }^{36}$ Empirical evidence by Mitchell et. al. (1999) illustrates that the load factor varies between $8 \%$ and $20 \%$ depending on different assumptions about discounting and mortality tables; a $20 \%$ value is suggested as indicative of the transaction cost involved and this is the baseline value we use in our calibration.

\subsubsection{Retirement Income}

At retirement the household has financial wealth $X_{1}$, which can be used to purchase an annuity. In addition, the household is endowed with pension income in each period, $L$, calibrated to be consistent with the available empirical evidence. Letting $r_{t+1,1}$ denote the one period interest rate, $\widetilde{r}_{t+1}$ the random return on the stock market and $\alpha_{t}$ the share of wealth in stocks, the evolution of cash-on-hand can be written as:

\footnotetext{
${ }^{36}$ The annuity premium/load factor $(P)$ and the money's worth are therefore defined as:

$$
\text { Annuity Cost }=(1+P) \times E P D V
$$
}

and

$$
\text { Money's Worth }=\frac{E P D V}{\text { AnnuityCost }} .
$$




$$
X_{t+1}=\left(X_{t}-C_{t}\right) \exp \left(\alpha_{t} \widetilde{r}_{t+1}+\left(1-\alpha_{t}\right) r_{t+1,1}\right)+L_{t+1}
$$

We assume no borrowing in retirement and no short sales of stocks so that $\alpha_{t}$ lies between zero and one.

\subsubsection{Preferences}

We model household saving, portfolio and annuity choices from retirement onwards at an annual frequency. The household lives for a maximum of $T$ (35) periods after retirement. We allow for uncertainty in the age of death with $p_{t}$ denoting the probability that the household is alive at date $t$, conditional on being alive at date $t-1\left(p_{1} \equiv 1\right)$. Household preferences are then described by the Epstein-Zin (1989) utility function:

$$
V_{t}=\left\{(1-\beta) C_{t}^{1-1 / \psi}+\beta\left(E_{t}\left(p_{t} V_{t+1}^{1-\gamma}+b\left(1-p_{t}\right) X_{t+1}^{1-\gamma}\right)\right)^{\frac{1-1 / \psi}{1-\gamma}}\right\}^{\frac{1}{1-1 / \psi}}
$$

where $\beta$ is the time discount factor, $b$ is the strength of the bequest motive, $\psi$ is the elasticity of intertemporal substitution (EIS) and $\gamma$ is the coefficient of relative risk aversion. The state variables in each period are current cash on hand, the annuity payment which will optimally be chosen at retirement, and age. In each period $t, t=1, \ldots, T$, the household chooses optimal consumption $C_{t}$ and the share of saving to invest in the stock market subject to a budget constraint. In the first period of retirement, the household also chooses the level of annuity to be purchased.

\subsubsection{Wealth Distribution and Pension Income}

To eventually compare the predictions of the model with the observed annuity demand and participation rates, we need (among other exogenous inputs) an initial wealth distribution and a reasonable pension level, and we take both of these from the data. At the same time, based on our empirical results, we also condition on stock market participation status and solve two different models, one in which stock market participation is allowed and another where access to the stock market does not exist, therefore requiring different inputs for wealth and pension income depending on the stock market participation status. Using these 
exogenous inputs we then compute the average annuity participation rate, average portfolio demand and the aggregate demand for annuities.

To match the definition of wealth in our model to the one in the data we add household pension income and financial wealth (wealth in financial assets, excluding retirement and housing wealth) for individuals aged between 55 and 70. Pension income is the median pension income received by retired individuals and for simplicity we set it to a constant that differs depending on stock market participation status. ${ }^{37}$

\subsubsection{Mortality Probabilities}

Period one is taken to be age 65 and conditional survival probabilities for the typical household are taken from the U.K. Government Actuary's Department (GAD) for 2002-2004.

\subsubsection{Solution Technique and Other Parameters}

This problem cannot be solved analytically. Given the finite nature of the problem a solution exists and can be obtained by backward induction, while we assume decisions are taken at an annual frequency. We assume a constant interest rate equal to $2 \%$. The mean equity premium is set at $4 \%$ with a standard deviation of $18 \%$. In the baseline case we use a CRRA preference specification with a coefficient of relative risk aversion equal to $3(\psi=1 / 3)$ and a discount factor equal to 0.98 .

\subsection{Results}

\subsubsection{Annuity Policy Functions}

We now report a series of comparative statics results to understand household choices according to this model. Figure 4 plots the annuity demand choice as a function of wealth at the time of retirement for households that have access to the stock market (stockholders) and

\footnotetext{
${ }^{37}$ There is a positive relationship between pension income and financial wealth in the data but a flat pension here makes the model simpler to solve and serves a conservative approach. Specifically, since increasing private pensions crowds out annuity demand (both in the data and in the model) we create an upward bias in average annuity demand generated by the model when we use a flat pension.
} 
households that make annuity choices without access to the stock market (non-stockholders). For both cases, the demand for annuities is zero for low wealth levels reflecting mainly the annuity in the form of pension income received during retirement. Higher wealth levels generate a monotonically increasing demand for annuities. From the shape of the policy function it should be immediately noted that the wealth distribution is a necessary input before pronouncing the presence of an annuity market participation puzzle. In an economy where all households are very poor, the model predicts that no annuity demand will be generated and therefore the lack of annuity market participation is not a puzzle but rather a prediction of the model.

Access to the stock market makes the wealth level that warrants entry to the annuity market surprisingly higher. This is consistent with the idea that households might value the flexibility that can be offered by investing in a higher mean return asset more than the security of an annuity payout. ${ }^{38}$ We find this result quite surprising given the relatively low equity premium $(4 \%)$ and the fact that we ignore any stock market predictability that can make the risk/return trade-off from stock market investments even more advantageous. We also note that this result is consistent with the idea that stock market participation might be related to annuity market participation (an idea that received empirical support in the previous section). Nevertheless, the comparative statics result here could lead us to conclude that access to the stock market decreases the demand for annuities, contrary to what we observe in the data. This conclusion is incorrect, however, since simulations must also be done to compute the total annuity demand given that stockholders are richer and are therefore more likely than non-stockholders to be very much to the right tail of the wealth distribution and therefore generate a higher average demand for annuities. We investigate this issue later on in the paper. ${ }^{39}$

\footnotetext{
${ }^{38}$ Variable annuities, which are linked to a broad stock market index, allow the investor to combine protection against longevity risk with stock market exposure. Koijen et al. (2006) show that access to variable annuities during retirement is welfare enhancing.

${ }^{39}$ Due to space limitations we do not report comparative statics that illustrate how a stronger bequest motive reduces annuity demand for a given level of cash on hand (when annuity demand is positive). At the same time a stronger bequest motive also increases the wealth level that triggers entry in the annuity market. Moreover, a higher risk aversion increases annuity demand, as predicted by the theory. The effects
} 


\subsubsection{Simulated Consumption and Wealth Profiles}

Given that we have computed policy functions for annuity demands as a function of financial wealth and given the initial observed wealth distribution in the data, we can simulate the evolution of individual consumption, portfolio choice, annuity demand and wealth for the remainder of a household's lifetime.

Figure 5 graphs the consumption profile during retirement for a median-wealth nonstockholder for two cases (profiles for stockholders are qualitatively the same). The first is the baseline case. Optimal consumption is decreasing during retirement given the assumptions about the survival probabilities, the discount factor and the rates of return and consumption remains constant at the pension plus the annuity payout after a few periods. The wealth profiles (omitted for brevity) reflect these consumption choices. Wealth drops at retirement to purchase the annuity and is gradually decumulated to zero when consumption becomes equal to the pension plus the annuity payout. In the same figure we also report results assuming a $0 \%$ load factor (actuarially fair annuity pricing). Consumption is higher during retirement in this case. This reflects the higher level of annuities purchased at retirement at a lower price. Correspondingly, financial wealth drops by more at retirement.

\subsubsection{Portfolio Choice Policy Functions}

The share of wealth invested in the stock market as a function of cash on hand and age is familiar from the literature on life-cycle portfolio choice. ${ }^{40}$ Specifically, pension income is of the elasticity of intertemporal substitution on annuity demand are non-monotonic and the sign depends on the strength of the bequest motive. For most parameter configurations, a higher elasticity of intertemporal substitution (from $\psi=0.3$ to $\psi=0.8$ ) increases annuity demand since a higher EIS typically leads to higher saving for this preference configuration and part of that saving is channelled in annuities. In the presence of a strong bequest motive, on the other hand, the household does not want to increase saving through the annuity market since higher saving is done not only for intertemporal smoothing reasons but, more importantly, for leaving bequests. As a result, the (unreported) effects from higher EIS on the annuity policy functions are reversed in the presence of a strong bequest motive and a higher EIS can generate a lower demand for annuities.

${ }^{40}$ For instance, see Cocco, Gomes and Maenhout (2005), Gomes and Michaelides (2005) and Polkovnichenko (2006). 
treated like an implicit bond since it is certain and therefore the share of wealth in stocks is a decreasing function of cash on hand since for diversification purposes the investor allocates all financial saving to the stock market. For higher levels of financial wealth to pension income, the portfolio becomes more diversified with more riskless assets added to the portfolio but given that there is no background risk (like uncertainty about medical expenditures) in the model, the portfolio remains heavily invested in the stock market.

An interesting finding is the important role of the bequest motive in generating a more balanced portfolio between bonds and stocks. As death approaches, a stronger bequest motive makes the household care more about rate of return uncertainty. The household derives utility from bequeathing wealth and since there is a probability of death in every period the stronger bequest motive generates a more balanced portfolio. The effect appears to be quite important quantitatively and could be an interesting path for future research.

\subsubsection{Participation, Annuity Demand and Annuity Value}

Given that we have computed policy functions for annuity demands as a function of financial wealth at retirement age and given the observed wealth distribution in the data, we can combine this information to calculate the total level of annuity demand implied by the model, as well as the percentage of households that will participate in the annuity market. We also calculate and report the annuity equivalent wealth (AEW) that will make an individual without access to the annuity market indifferent between purchasing the optimal annuity for the given preference configuration and economic environment or staying outside the market. ${ }^{41}$ The maximum welfare when annuities are set to zero is calculated by solving the consumer's problem by setting annuities equal to zero, giving a value function equal to $V$, while the optimal decision with a potentially positive annuity is given by the value function $V^{*}$. We then solve for the percentage change in liquid wealth that will equate the two value functions for a given level of wealth as

$$
V\left(X\left(1+\frac{\Delta X}{X}\right)=V^{*}(X)\right.
$$

\footnotetext{
${ }^{41}$ This calculation follows Brown (2001).
} 
The AEW is therefore given by $1+\frac{\Delta X}{X}$; a number like $99 \%$ means that the household is willing to give up $1 \%$ of its wealth to be able to purchase an annuity, that is, annuities are welfare improving to individuals. Following the distinction we view as empirically relevant, we also condition on the stock market participation status when presenting these results.

Table 5, Panel A, reports various annuity demand statistics for non-stockholders for different perturbations of the preference parameters (risk aversion, the elasticity of intertemporal subsitution and the bequest motive). ${ }^{42}$ Annuity market participation (column 4) reports the percentage of households that participate in the annuity market, while voluntary annuity demand (column 5) reports the average annual annuity income in thousands of pounds conditional on participation. Column 6 reports the share of wealth being annuitized at retirement. The last column reports average annuity equivalent wealth, as defined above. Consistent with the policy function results, a higher risk aversion coefficient increases annuity market participation, the total level of annuity demand ${ }^{43}$ and the share of wealth being annuitized at retirement. A stronger bequest motive, on the other hand, decreases all three measures of annuity demand, while the EIS generally increases annuity demand but the effect is non-monotonic when the bequest motive is operating. As annuity demand increases, the value of annuities is reflected in a lower $\mathrm{AEW}$. In the absence of a bequest motive, this can rise to $11 \%$ of wealth (for $\gamma=5$ and $\psi=0.8$ ) illustrating the value of annuities for more risk averse households with a high EIS.

Quantitatively, the results illustrate that in the absence of a bequest motive, annuity market participation is quite high but there do exist configurations of parameters where the model still predicts low participation. When $\gamma=2$ and $\psi=0.2$, for instance, only $6.15 \%$ of households choose to participate in the annuity market and they annuitize around one third of their wealth. This result seems very surprising given the existing literature on the annuity market participation puzzle. What explains this finding? This preference parameter

\footnotetext{
${ }^{42} \mathrm{We}$ use a range of preference parameters that is deemed reasonable in the literature either through calibration or through estimation results (see, for example, Gourinchas and Parker (2002) and VissingJorgensen (2002)).

${ }^{43}$ The reported average level of voluntary annuity demand falls but the total annuity demand rises since there are more participants now. We report this statistic because this will be more directly comparable to the empirical section which reports per capita annuity income conditional on participation.
} 
configuration implies a weak motive to save, while the pension system already provides a substitute for the provision of longevity insurance. As a result, very few households choose to participate in the annuity market. This explanation is consistent with the other finding from the table that as risk aversion increases, the insurance value of annuities rises substantially and annuity market participation can rise up to $67 \%$ (for $\gamma=5$ and $\psi=0.5$ or $\psi=0.8$ ).

The table also illustrates that lower annuity demand can also be generated for higher risk aversion if one is willing to admit some preference for leaving bequests. Specifically, for $\{\gamma=3, \psi=0.3\}$ and $b=1$ annuity market participation is around $10 \%$ and around one third of wealth is annuitized at retirement (38\%). For this preference configuration, the average household is expected to leave around 22,000 GBP as bequests, if it lives until the end of its possible life.

Similar results arise for the stockholders case (Panel B). Annuity demand and participation are both increasing in risk aversion and decreasing in the strength of the bequest motive, while the effect of EIS is ambiguous/non-monotonic and depends on the presence of a bequest motive. Even though the policy functions showed that stock market participation implies that a much higher wealth is needed to participate in the annuity market, the annuity participation column gives similar results to the ones we obtain for non-stockholders. This is readily explained by the wealth distribution that is exogenously fed in the model to generate these numbers: stockholders come from a richer part of the population and therefore the final reported participation rates tend to be relatively similar across the two experiments, even though for stockholders a much higher wealth threshold is needed before participating in the annuity market. As before, the AEW decreases with higher annuity demand and can rise to $5 \%$ of wealth for $\gamma=5$ and $\psi=0.8$, in the absence of a bequest motive.

\subsection{Summary}

We have used a life-cycle model to understand both qualitatively and quantitatively the importance of preference parameters in affecting the demand for annuities. Preference parameters like risk aversion, the strength of the bequest motive and the elasticity of intertemporal substitution and the decision to access the stock market are key determinants of the model's 
quantitative predictions. Financial wealth is a key endogenous state variable in the model, is directly affected by these parameters and is therefore a key predictor variable in assessing the model's quantitative implications. Contrary to frictionless theoretical models, the model does not predict that all households should purchase an annuity since a reasonably calibrated pension income level provides substantial insurance already. In fact, there exist reasonable preference parameter configurations that generate very low annuity market participation.

\section{How Deep is the Puzzle?}

In this section we perform a small empirical exercise to evaluate the extent to which the model's predictions are at odds with the data. We employ a simple method of simulated moments estimator to pick the structural parameters that minimize the distance between some selected moments in the data and in the model. The main predictions that we focus on are the participation in the annuity market, and, conditional on participation, the amount of annuity demand at retirement and the share of wealth annuitized. Consistent with the empirical evidence from the previous sections, we separate our analysis between stockholders and non-stockholders. In both estimated models we have three parameters to match three moments but we constrain the parameter set to lie in a "reasonable" parameter space. This means that we basically restrict the risk aversion coefficient to be less than 10 essentially, and the elasticity of intertemporal substitution to be less than 2 .

\subsection{Non-Stockholders}

Given the wealth distribution for non-stockholders at retirement as an exogenous input, Table 6, Panel A, reports the estimated structural parameters from this procedure. ${ }^{44}$ The

\footnotetext{
${ }^{44}$ The parameter vector $(\theta)$ is chosen to minimize the quadratic form $\operatorname{Argmin}_{\theta} D^{\prime} \Omega^{-1} D$. Under regularity conditions given in Duffie and Singleton (1993), $\sqrt{T}(\hat{\theta}-\theta) \rightarrow N\left(0, W_{H}\right)$. The different components of the quadratic are defined as follows,

$$
D=\left(\frac{1}{T} \sum_{t=1}^{T} m\left(Y_{t}\right)-\frac{1}{T H} \sum_{t=1}^{T H} m\left(\tilde{Y}_{t}\right)\right)
$$
}


risk aversion parameter is estimated at around 1.5, the elasticity of intertemporal substitution at around 0.5 and there is some evidence for a bequest motive (parameter equals 0.2). These preference parameters are consistent with parameter estimates from other lifecycle studies (Gourinchas-Parker (2002)) or studies based on intertemporal Euler equations (Vissing-Jorgensen (2002)) and they also imply that the model is not far off from a CRRA specification. The predicted annuity market participation rate for this group of households is around $4.3 \%$ (versus $3.2 \%$ in the data). Conditional on participation, the annual annuity purchased is around 3, $950 \mathrm{GBP}$ (versus 1,650 GBP in the data) and the share of wealth being annuitized is around $20.4 \%$ (versus $36.6 \%$ in the data). There is therefore some distance between the final actual moments and the data but given the standard deviations of the three moments in the data and given our original prior that the model will never generate anything resembling reality, we view the predicted outcomes as quite good approximations of reality. It should be noted that non-stockholders holding annuities are a proportionately much smaller group and therefore more notable deviations from the data for this group are less important in trying to match total annuity demand in the data, as the next subsection will show. We think that the intuition for these results is clear. The wealth distribution for non-stockholders is concentrated very much to the left of the wealth distribution and poor households optimally choose not to annuitize or annuitize a small fraction of their wealth since pension income already provides a reasonable insurance against longevity risk.

It could be argued that our results are arising from certain exogenous assumptions in the model. For instance, we use a load factor of $20 \%$ which might be considered very high. We therefore next investigate the robustness of our results to such maintained assumptions for

$$
\begin{gathered}
\Omega=\operatorname{Var}\left(\frac{1}{\sqrt{T}} \sum_{t=1}^{T} m\left(Y_{t}\right)\right) \\
W_{H}=\left(1+\frac{1}{H}\right)\left(E\left[\frac{\partial m\left(\tilde{Y}_{[T H]}\right)^{\prime}}{\partial \theta}\right] \Omega^{-1} E\left[\frac{\partial m\left(\tilde{Y}_{[T H]}\right)}{\partial \theta}\right]\right)^{-1}
\end{gathered}
$$

$m\left(Y_{t}\right)$ denotes the different moments chosen, variables $Y,(\tilde{Y})$ denote actual (simulated) data, $T$ is the sample size and $T H$ is the total size of simulated data. Following the rules of thumb in Michaelides and $\mathrm{Ng}$ (2000) we use $H=10$. The derivatives are computed numerically and $E$ is the population average (sample analog used in the estimation). 
which information might not be very accurate. Table 7, Panel A, reports the results from changing these parameters while maintaining everything else as in the estimated model. A lower pension (set at the 25th percentile) increases annuity market participation from $4.25 \%$ to $4.99 \%$, whereas a higher pension (75th pension percentile) decreases participation to $3.25 \%$. Nevertheless, the results with regards to the three moments of interest are still relatively close to their empirical counterparts, if one takes into account the standard deviation of these moments in the data. We next investigate the implications of a lower subjective survival probability (the household expects the survival probability to be $10 \%$ lower than the objective one). This expectation drives annuity demand to zero and the result is consistent with the multivariate probit analysis in Section 2. We also investigate what happens when an actuarially fair annuity policy exists. This change increases annuity participation from $4.25 \%$ to $15.25 \%$ and voluntary annuity demand from 3,950 GBP to 4,760 GBP. These results indicate that there is a range of possible outcomes that the model can generate depending on exogenous assumptions, but we view as robust the basic message that there exist preference parameters that can replicate the observed data as part of a structural, rational choice model.

\subsection{Stockholders}

We follow the same estimation procedure for stockholders and report the results in Table 6, Panel B. The risk aversion coefficient is estimated at around 2.2, the elasticity of intertemporal substitution is around 0.59 and the bequest parameter equals 0.1 . These parameters are not very different relative to the ones for non-stockholders and are also an intuitively reasonable preference specification that is again consistent with the empirical evidence offered in Vissing-Jorgensen (2002). The level of annuity market participation is around $10.4 \%$ ( $9.6 \%$ in the data), with $24 \%$ of financial wealth being annuitized at retirement (26\% in the data), giving an annual annuity income of around 5,304 GBP (3,656 GBP in the data). We view these predicted outcomes as quite close to their observed coutnerparts; in fact, these predictions are much closer to the data than the ones for non-stockholders. Given that stockholders are more likely to hold annuities than non-participants in the stock market, the 
structural model implies a good overall fit to the data.

There is one caveat to the implications for stockholders. Our model is intentionally simple and abstracts from any background risks that older households might face (health risk, for instance). As a result, the portfolio held by the household is heavily invested in the stock market, since with the provision of reasonable pension income and a certain annuity income, the natural prediction of the model is that households would hold stocks to have a diversified portfolio (since annuities and pension income act implicitly like bonds/riskless assets). In our preferred specifications, the share of wealth in stocks is around $95-98 \%$ and that typically decreases to around $50 \%$ in the presence of the strong bequest motive. We do think that this is a potentially counterfactual prediction but we also think that the introduction of further risks (like health expenditures) in the model (for which liquid balances will be needed) will work towards both reducing annuity demand and generating a more conservative portfolio, an interesting avenue for further research.

In Table 7, Panel B, we offer some further comparative statics to illustrate that the data can be replicated by not only perturbing preference parameters. Higher and lower pension levels affect the participation rate in the expected way and the subjective survival probability change again reduces annuity market participation. The results therefore illustrate that a low level of annuity market participation can be a prediction of a reasonably calibrated model and that they are robust to substantial changes in underlying parameters.

\section{Conclusion}

We provide an in depth empirical analysis of the characteristics of households that participate (or not) in the U.K. voluntary annuity market. We document that annuity demand increases in financial wealth, education and life expectancy, while it decreases in pension income and a possible bequest motive for surviving spouses. Moreover, we find that the annuitization behavior of stock market participants is better explained by a reduced form model than the behavior of non-participants. We then estimate a life-cycle model of household portfolio choice and annuity demand after retirement. The model emphasizes the role of access to stock market opportunities, bequests and risk aversion (and through these financial wealth) 
as main determinants of annuity demand. Comparing the predictions of the model with their empirical counterparts, we find that reasonable preference parameters can generate the low annuity demand observed in the data and that, therefore, the annuity market participation puzzle might not be as deep as previously thought.

\section{References}

Ameriks, John, Andrew Caplin, Steven Laufer and Stijn van Nieuwerburgh (2007): "The Joy of Giving or Assisted Living? Using Strategic Surveys to Separate Bequest and Precautionary Motives," NBER working paper 13105.

Attanasio, Orazio, and Susann Rohwedder (2003): "Pension Wealth and Household Saving: Evidence from Pension in the United Kingdom," American Economic Review, 93 (5), 1499-1522.

Banks, James, and Richard Blundell (2005): "Private Pension Arrangements and Retirement in Britain," Fiscal Studies, 26 (1), 35-53.

Banks, James and Carl Emmerson (1999): "UK Annuitants," Institute of Fiscal Studies.

Berndt, Ernst K., Bronwyn H. Hall, Robert E. Hall, and Jerry A. Hausman (1974): “Estimation and Inference in Nonlinear Structural Models," Annals of Economic and Social Measurement, 653-65.

Bernheim, B. Douglas (1991): "How Strong are Bequest Motives? Evidence Based on Estimates of Demand for Life Insurance and Annuities," Journal of Political Economy, $99(5), 899-927$.

Blake, David (2003): "The United Kingdom Pension System: Key Issues," UBS Pensions Research Programme Discussion Paper No. 11, LSE.

Blundell, Richard, Costas Meghir, and Sarah Smith (2002): "Pensions Incentives and the Pattern of Early Retirement," Economic Journal, 112, 153-170. 
Brown, Jeffrey R. (2001). "Private Pensions, Mortality Risk and The Decision to Annuitize," Journal of Public Economics, 82, pp. 29-62.

Brown, Jeffrey R., Olivia S. Mitchell, and James M. Poterba (2001): "The Role of Real Annuities and Indexed Bonds in an Individual Accounts Retirement Program," in Risk Aspects of Investment-Based Social Security Reform, ed. John Y. Campbell and Martin Feldstein.

Brown, Jeffrey R., and James M. Poterba (2006): "Household Ownership of Variable Annuities," NBER Working Paper 11964.

Campbell, John Y. (2006): "Household Finance," The Journal of Finance, Vol. LXI, No.4, 1553-1604.

Cocco, Joao, Francisco Gomes, and Pascal Maenhout (2005): "Portfolio Choice Over The Life Cycle," Review of Financial Studies, 18, 491-533.

Davidoff, Thomas, Jeffrey R. Brown and Peter Diamond (2005): "Annuities and Individual Welfare," American Economic Review, 95(5), 1573-1590.

Duffie, Darrell, and Kenneth Singleton (1993): "Simulated Moments Estimation of Markov Models of Asset Prices" Econometrica Vol.61, No. 4, 929-952.

Dushi, Irena and Anthony Webb (2004): "Household Annuitization Decisions: Simulations and Empirical Analysis," Journal of Pension Economics and Finance, 3(2), 109-143.

Epstein, Lawrence, and Stanley Zin (1989): "Substitution, Risk Aversion, and the Temporal Behavior of Consumption and Asset Returns: A Theoretical Framework," Econometrica, 57, 937-969.

Finkelstein, Amy, and James M. Poterba (2002): "Selection Effects in the United Kingdom Individual Annuities Market," The Economic Journal, 112, 28-42.

Finkelstein, Amy, and James Poterba (2004): "Adverse Selection in Insurance Markets: Policyholder Evidence from the U.K. Annuity Market," Journal of Political Economy, 112, 1 (1), 183-208. 
Friedman, Benjamnin M., and Mark J. Warshawsky (1990): "The Cost of Annuities: Implications for Saving Behavior and Bequests," Quarterly Journal of Economics, 105, $135-154$.

Gomes, Francisco, and Alexander Michaelides (2005): "Optimal Life-Cycle Asset Allocation: Understanding the Empirical Evidence," Journal of Finance, 60, 869-904.

Gourinchas, Pierre-Olivier, and Jonathan Parker (2002): "Consumption over the Life Cycle." Econometrica, 70 (1), 47-89.

Government Actuary's Department (2006): Interim Life Tables, using data for the years 2002-2004, available online from the web site of GAD.

Hurd, Michael D., and Kathleen McGarry (1995): "Evaluation of the Subjective Probabilities of Survival in the Health and Retirement Study," Journal of Human Resources, 30 Supplement, 268-292.

Hurd, Michael D., and Kathleen McGarry (2002): "The Predictive Validity of Subjective Probabilities of Survival," Economic Journal, 112, 966-985.

Koijen, Ralph, Theo Nijman, and Bas Werker (2006): "Optimal Portfolio Choice with Annuitization," Netspar Discussion Paper, 2006-017.

Lopes, Paula (2006): "The Effect of Load Factors and Minimum Size Restrictions on Annuity Market Participation" LSE FMG Discussion Paper.

Lopes, Paula, and Alexander Michaelides (2007): "Rare Events and Annuity Market Participation," Finance Research Letters, vol. 4, pp.82-91.

Lusardi, Annamaria, and Olivia S. Mitchell (2006): "Baby Boomers Retirement Security: The Roles of Planning, Financial Literacy, and Housing Wealth," Journal of Monetary Economics, forthcoming.

Marmot, Michael, et al. (2006): English Longitudinal Study of Ageing: Waves 1-2, 20022005 [computer file]. 4th Edition. Colchester, Essex: UK Data Archive [distributor], $\mathrm{SN}: 5050$. 
Michaelides, Alexander, and Serena Ng (2000): "Estimating the Rational Expectations Model of Speculative Storage: A Monte Carlo Comparison of Three Simulation Estimators", Journal of Econometrics, Volume 96, (2), pp. 231-266.

Milevsky, Moshe A., and Virginia Young (2002): "Optimal Asset Allocation and the Real Option to Delay Annuitization: It's Not Now or Never," Discussion Paper PI-0211, Birbeck College, London.

Mitchell, Olivia S., James M. Poterba, Mark Warshawsky, and Jeffrey R. Brown (1999): "New Evidence on Money's Worth of Individual Annuities," American Economic Review, 89, 1299-1318.

Pensions Commission (2004): Pensions: Challenges and Choices. The First Report of the Pensions Commission. The Stationery Office.

Polkovnichenko, Valery (2006): "Life Cycle Consumption and Portfolio Choice with Additive Habit Formation Preferences and Uninsurable Labor Income Risk," Review of Financial Studies, forthcoming.

Prelec, Drazen (1998): “The Probabiliy Weighting Function," Econometrica, 66 (3), 497527.

Rosen, Harvey and Stephen Wu (2004): "Portfolio Choice and Health Status", Journal of Financial Economics, 72, 457-484.

Sinclair, Sven H., and Kent A. Smetters (2004): "Health Schocks and the Demand for Annuities, " Technical Paper Series 2004-9, Congressional Budget Office.

Turra, Cassio M., and Olivia Mitchell (2004): "The Impact of Health Status and Outof-Pocket Medical Expenditures an Annuity Valuation," Working Paper, Pension Research Council WP 2004-2.

Vissing-Jørgensen, Annette (2002): "Limited Asset Market Participation and the Elasticity of Intertemporal Substitution", Journal of Political Economy, 110, 825-53. 
Webb, David (2005): "Mortality Insurance, Health Care and Bequests," FMG Discussion Papers, 530, London School of Economics.

White, Halbert L. (1980): "A Heteroskedasticity-Consistent Covariance Matrix Estimator and a Direct Test for Heteroskedasticity," Econometrica, 48, 817-838.

Yaari, Menahem (1965): "Uncertainty Lifetime, Life Insurance and the Theory of the Consumer," Review of Economics Studies, 32, 137-150. 
Table 1: Annuity and stock market participation

\begin{tabular}{|c|c|c|c|}
\hline & $A=0$ & $A=1$ & Total \\
\hline$S=0$ & 2917 & 96 & 3013 \\
\hline Row- $\%$ & 96.8 & 3.2 & 100.0 \\
\hline Total-\% & 55.7 & 1.8 & 57.5 \\
\hline$S=1$ & 2007 & 213 & 2220 \\
\hline Row-\% & 90.4 & 9.6 & 100.0 \\
\hline Total-\% & 38.4 & 4.1 & 42.5 \\
\hline Total & 4924 & 309 & 5233 \\
\hline Total-\% & 94.1 & 5.9 & 100.0 \\
\hline
\end{tabular}

Notes to Table 1: The table presents the number of sample members in sub-samples defined by participation in the voluntary annuity market $(\mathrm{A})$ and the stock market $(\mathrm{S})$. " $\mathrm{A}=1$ " ("A = 0") refers to annuity market (non-) participants in 2002 or 2004 while "S = 1" ("S = 0") refers to stock market (non-) participants in 2002. Percentages are either row percentages of the subsamples of non-stockholders and stockholders, respectively, or percentages of the total sample size. The sample consists of retired households in the first (2002) wave of the English Longitudinal Study of Ageing (ELSA). 
Table 2: Financial wealth and annual income by annuity and stock market participation

\begin{tabular}{lrrrrrr}
\hline \hline & \multicolumn{2}{c}{ All } & \multicolumn{2}{c}{$\mathrm{A}=1$} & \multicolumn{2}{c}{$\mathrm{A}=0$} \\
& Mean & Median & Mean & Median & Mean & Median \\
\hline Financial wealth & 55031 & 15800 & 135017 & 65000 & 50011 & 14200 \\
Annual pension & 9328 & 7305 & 12182 & 9036 & 9149 & 7228 \\
Annual public pension & 4796 & 4732 & 4945 & 4940 & 4787 & 4723 \\
Annual private pension & 4532 & 1440 & 7236 & 3200 & 4362 & 1350 \\
Annual annuity income & 179 & 0 & 3032 & 984 & - & - \\
Stock share percentage & 16 & 0 & 24 & 14 & 16 & 0 \\
\hline & $\mathrm{A}=1$ and S=1 & $\mathrm{S}=1$ & & $\mathrm{~S}=0$ & \\
& $\mathrm{Mean}$ & Median & Mean & Median & Mean & Median \\
\hline Financial wealth & 173619 & 99300 & 101937 & 4786 & 20470 & 5000 \\
Annual pension & 14142 & 11660 & 11523 & 9132 & 7711 & 6315 \\
Annual public pension & 4943 & 4948 & 4521 & 4628 & 4999 & 4784 \\
Annual private pension & 9199 & 6600 & 7002 & 4145 & 2712 & 500 \\
Annual annuity income & 3656 & 1200 & 351 & 0 & 53 & 0 \\
Stock share percentage & 35 & 28 & 38 & 32 & - & - \\
\hline
\end{tabular}

Notes to Table 2: The table presents mean and median wealth and income statistics (in GBP) and stock allocation percentages for the whole sample ("All”) and sub-samples defined by participation in the voluntary annuity market $(\mathrm{A})$ and the stock market $(\mathrm{S})$. "A = 1" (“A = 0") refers to annuity market (non-) participants in 2002 or 2004 while "S = 1" ("S =0") refers to stock market (non-) participants in 2002. The sample consists of 5,233 retired households from the first (2002) wave of the English Longitudinal Study of Ageing (ELSA). 
Table 3: Socio-economic background, health and life-expectancy

\begin{tabular}{lccc}
\hline \hline & All & $\mathrm{A}=1$ & $\mathrm{~A}=0$ \\
\hline Age / 10 & 6.93 & 6.82 & 6.94 \\
Female & 0.53 & 0.42 & 0.54 \\
Married & 0.56 & 0.57 & 0.56 \\
Number of children & 2.04 & 1.98 & 2.04 \\
Low education & 0.59 & 0.34 & 0.61 \\
Medium education & 0.30 & 0.41 & 0.30 \\
High education & 0.10 & 0.25 & 0.10 \\
\hline Survival probability & 0.52 & 0.57 & 0.52 \\
Objective GAD probability & 0.53 & 0.56 & 0.53 \\
Bad health condition & 0.19 & 0.14 & 0.19 \\
Medium health condition & 0.62 & 0.60 & 0.63 \\
Good health condition & 0.19 & 0.27 & 0.18 \\
\hline
\end{tabular}

Notes to Table 3: The table presents averages for all sample members ("All"), voluntary annuity market participants ("A = 1") in either 2002 or 2004, and annuity market non-participants ("A = 0"). The sample consists of 5,233 retired households from the first (2002) wave of the English Longitudinal Study of Ageing (ELSA). 
Table 4: Estimation results

A. Non-stockholders

\begin{tabular}{|c|c|c|c|c|c|c|}
\hline \multirow[b]{3}{*}{ Variable } & \multicolumn{4}{|c|}{ Voluntary annuity market participation } & \multirow{2}{*}{\multicolumn{2}{|c|}{$\begin{array}{l}\text { Log annuity demand } \\
\text { cond. on participation }\end{array}$}} \\
\hline & \multicolumn{2}{|c|}{ Probit } & \multicolumn{2}{|c|}{ Marginal effects } & & \\
\hline & estimate & t-value & estimate & t-value & estimate & t-value \\
\hline Intercept & -4.0431 & -1.50 & - & - & 4.8683 & 0.59 \\
\hline Age / 10 & 0.5708 & 0.72 & -0.0042 & -0.35 & -0.6805 & -0.28 \\
\hline $\mathrm{Age}^{2} / 100$ & -0.0462 & -0.82 & - & - & 0.0527 & 0.31 \\
\hline Female & -0.1708 & -1.77 & -0.0214 & -1.62 & -0.0327 & -0.10 \\
\hline Married & -0.3231 & -2.98 & -0.0361 & -2.42 & 0.1729 & 0.52 \\
\hline Number of children & 0.0390 & 1.58 & 0.0057 & 1.64 & 0.1053 & 0.84 \\
\hline Low education & -0.2254 & -2.10 & -0.0271 & -1.87 & 0.1988 & 0.61 \\
\hline High education & 0.2027 & 1.13 & 0.0331 & 1.04 & 0.1525 & 0.25 \\
\hline Survival probability & 0.0290 & 0.18 & 0.0041 & 0.18 & 0.4178 & 0.63 \\
\hline Log financial wealth & 0.1627 & 5.10 & 0.0231 & 3.56 & 0.3324 & 2.17 \\
\hline Log pension & -0.0783 & -1.49 & -0.0111 & -1.49 & -0.0463 & -0.46 \\
\hline Number of observations & & & & & & \\
\hline Fit of the model & $\mathrm{Co}$ & ect predi & ions: 96.8 & & R-square & $3.60 \%$ \\
\hline
\end{tabular}


Table 4 (continued): Estimation results

B. Stockholders

\begin{tabular}{|c|c|c|c|c|c|c|}
\hline \multirow[b]{3}{*}{ Variable } & \multicolumn{4}{|c|}{ Voluntary annuity market participation } & \multirow{2}{*}{\multicolumn{2}{|c|}{$\begin{array}{l}\text { Log annuity demand } \\
\text { cond. on participation }\end{array}$}} \\
\hline & \multicolumn{2}{|c|}{ Probit } & \multicolumn{2}{|c|}{ Marginal effects } & & \\
\hline & estimate & t-value & estimate & t-value & estimate & t-value \\
\hline Intercept & -10.279 & -4.65 & - & - & -1.2919 & -0.23 \\
\hline Age / 10 & 1.7066 & 2.58 & 0.0280 & 2.76 & 0.9186 & 0.57 \\
\hline $\mathrm{Age}^{2} / 100$ & -0.1167 & -2.40 & - & - & -0.0706 & -0.60 \\
\hline Female & -0.1666 & -1.98 & -0.0218 & -1.77 & -0.1179 & -0.54 \\
\hline Married & -0.3026 & -3.10 & -0.0359 & -2.69 & 0.0691 & 0.28 \\
\hline Number of children & 0.0135 & 0.46 & 0.0020 & 0.47 & 0.0440 & 0.65 \\
\hline Low education & -0.2065 & -2.23 & -0.0263 & -2.04 & -0.0583 & -0.22 \\
\hline High education & 0.1587 & 1.64 & 0.0262 & 1.55 & -0.1158 & -0.56 \\
\hline Survival probability & 0.3205 & 1.98 & 0.0473 & 1.92 & 0.3446 & 0.85 \\
\hline Log financial wealth & 0.2439 & 7.08 & 0.0360 & 5.62 & 0.6303 & 6.88 \\
\hline Log pension & 0.0292 & 0.63 & 0.0043 & 0.63 & -0.2203 & -1.99 \\
\hline Number of observations & & & & & 21 & \\
\hline Fit of the model & Cor & ect predi & ons: 90.4 & & R-square & $2.45 \%$ \\
\hline
\end{tabular}

Notes to Table 4: The table reports estimation results from a Probit model for the annuity market participation decision and from a linear regression model for the (log) annuity demand conditional on participation. Panel A shows results for non-stockholders, Panel B for stockholders. The Probit participation model is estimated with ML using the Berndt et al. (1974) estimator of asymptotic standard errors. The marginal effects are calculated for a 65 years old single male without children, medium education, average subjective survival probability, average pension and average wealth. The asymptotic distribution of marginal effects is computed with the delta method. The linear annuity demand model is estimated with OLS using White's (1980) heteroskedasticity-consistent estimator of asymptotic standard errors. The sample consists of retired households in the first (2002) wave of the English Longitudinal Study of Ageing (ELSA). 
Table 5: Average annuity demand and annuity market participation

A. Non-stockholders

\begin{tabular}{|c|c|c|c|c|c|c|}
\hline$b$ & $\gamma$ & $\psi$ & $\begin{array}{c}\text { Voluntary } \\
\text { annuity market } \\
\text { participation }\end{array}$ & $\begin{array}{l}\text { Voluntary } \\
\text { annuity } \\
\text { demand }\end{array}$ & $\begin{array}{c}\text { Share } \\
\text { of wealth } \\
\text { annuitized }\end{array}$ & $\begin{array}{l}\text { Annuity } \\
\text { equivalent } \\
\text { wealth }\end{array}$ \\
\hline \multirow{12}{*}{0} & \multirow{4}{*}{2} & 0.20 & 6.15 & 5.79 & 34.12 & 99.75 \\
\hline & & 0.30 & 12.80 & 4.57 & 37.73 & 99.53 \\
\hline & & 0.50 & 34.50 & 2.93 & 54.16 & 98.73 \\
\hline & & 0.80 & 66.75 & 2.10 & 92.96 & 91.99 \\
\hline & \multirow{4}{*}{3} & 0.20 & 22.10 & 3.62 & 44.30 & 99.11 \\
\hline & & 0.30 & 41.05 & 2.73 & 62.30 & 98.02 \\
\hline & & 0.50 & 66.50 & 2.10 & 93.31 & 94.98 \\
\hline & & 0.80 & 67.10 & 2.09 & 92.49 & 90.21 \\
\hline & \multirow{4}{*}{5} & 0.20 & 51.00 & 2.42 & 68.98 & 96.87 \\
\hline & & 0.30 & 66.95 & 2.06 & 89.18 & 93.87 \\
\hline & & 0.50 & 67.10 & 2.09 & 92.53 & 91.57 \\
\hline & & 0.80 & 67.30 & 2.08 & 92.16 & 89.36 \\
\hline \multirow{12}{*}{1} & \multirow{4}{*}{2} & 0.20 & 3.90 & 3.17 & 15.59 & 99.89 \\
\hline & & 0.30 & 4.00 & 3.39 & 16.73 & 99.88 \\
\hline & & 0.50 & 3.75 & 3.21 & 15.41 & 99.89 \\
\hline & & 0.80 & 1.05 & 0.65 & 2.51 & 99.90 \\
\hline & \multirow{4}{*}{3} & 0.20 & 9.25 & 5.15 & 35.35 & 99.61 \\
\hline & & 0.30 & 10.05 & 5.19 & 37.61 & 99.58 \\
\hline & & 0.50 & 10.05 & 5.29 & 38.41 & 99.58 \\
\hline & & 0.80 & 6.95 & 5.55 & 31.94 & 99.76 \\
\hline & \multirow{4}{*}{5} & 0.20 & 25.30 & 3.47 & 48.47 & 98.62 \\
\hline & & 0.30 & 29.40 & 3.23 & 50.69 & 98.34 \\
\hline & & 0.50 & 31.75 & 3.03 & 47.90 & 98.26 \\
\hline & & 0.80 & 22.10 & 3.61 & 40.41 & 98.95 \\
\hline
\end{tabular}


Table 5 (continued): Average annuity demand and annuity market participation

B. Stockholders

\begin{tabular}{|c|c|c|c|c|c|c|}
\hline$b$ & $\gamma$ & $\psi$ & $\begin{array}{c}\text { Voluntary } \\
\text { annuity market } \\
\text { participation }\end{array}$ & $\begin{array}{l}\text { Voluntary } \\
\text { annuity } \\
\text { demand }\end{array}$ & $\begin{array}{c}\text { Share } \\
\text { of wealth } \\
\text { annuitized }\end{array}$ & $\begin{array}{l}\text { Annuity } \\
\text { equivalent } \\
\text { wealth }\end{array}$ \\
\hline \multirow{12}{*}{0} & \multirow{4}{*}{2} & 0.20 & 5.45 & 2.79 & 11.62 & 99.84 \\
\hline & & 0.30 & 7.05 & 3.14 & 13.36 & 99.81 \\
\hline & & 0.50 & 9.85 & 4.71 & 21.10 & 99.67 \\
\hline & & 0.80 & 18.40 & 5.58 & 28.50 & 99.26 \\
\hline & \multirow{4}{*}{3} & 0.20 & 17.00 & 4.45 & 23.12 & 99.50 \\
\hline & & 0.30 & 20.60 & 4.68 & 25.94 & 99.36 \\
\hline & & 0.50 & 28.90 & 4.83 & 30.33 & 99.00 \\
\hline & & 0.80 & 40.80 & 5.12 & 38.15 & 98.23 \\
\hline & \multirow{4}{*}{5} & 0.20 & 43.25 & 4.92 & 39.04 & 97.81 \\
\hline & & 0.30 & 47.95 & 4.97 & 42.26 & 97.37 \\
\hline & & 0.50 & 57.00 & 4.96 & 47.81 & 96.55 \\
\hline & & 0.80 & 69.25 & 4.96 & 56.53 & 95.16 \\
\hline \multirow{12}{*}{1} & \multirow{4}{*}{2} & 0.20 & 4.30 & 2.16 & 8.68 & 99.87 \\
\hline & & 0.30 & 4.70 & 2.52 & 10.14 & 99.86 \\
\hline & & 0.50 & 5.30 & 3.37 & 13.54 & 99.85 \\
\hline & & 0.80 & 6.10 & 3.98 & 15.88 & 99.78 \\
\hline & \multirow{4}{*}{3} & 0.20 & 13.20 & 4.06 & 19.25 & 99.66 \\
\hline & & 0.30 & 14.25 & 4.34 & 21.00 & 99.61 \\
\hline & & 0.50 & 15.40 & 4.82 & 23.52 & 99.54 \\
\hline & & 0.80 & 12.30 & 5.25 & 23.46 & 99.57 \\
\hline & \multirow{4}{*}{5} & 0.20 & 39.25 & 4.89 & 36.57 & 98.22 \\
\hline & & 0.30 & 43.25 & 4.92 & 38.65 & 97.86 \\
\hline & & 0.50 & 49.25 & 4.86 & 40.36 & 97.46 \\
\hline & & 0.80 & 40.80 & 4.92 & 35.83 & 98.17 \\
\hline
\end{tabular}

Notes to Table 5: Panel A reports simulated results for the model without access to the stock market, using the wealth distribution from the data as an exogenous input to compute annuity demand statistics, while Panel B reports the simulated results using the model that allows access to the stock market and the respective empirical wealth distribution of stock market participants (2000 life-histories simulated). The risk free rate is set to $2 \%$, the equity premium at $4 \%$ and the standard deviation of the risky asset return at $18 \%$. Pre-existing pension income is 
set at each group's median value. Comparative statics are performed over several preference parameter combinations. The bequest parameter is set at $b=0$ and 1 , relative risk aversion $\gamma$ is 2,3 , or 5 and the elasticity of intertemporal substitution (EIS) $\psi$ is $0.2,0.3,0.5$, and 0.8 . Voluntary annuity market participation reports average participation in percentage terms, Voluntary annuity demand is defined as average annual annuity income in thousands of pounds, conditional on participation, and the voluntary Share of wealth annuitized is the optimal amount of purchased annuity at retirement as a percentage of total financial wealth at retirement. The Annuity equivalent wealth reports average AEW, which is defined as the wealth each individual is willing to give up in order to be able to access the annuity market.

Table 6: Estimated structural parameters using the Method of Simulated Moments.

A. Non-stockholders

\begin{tabular}{ccccccc}
\hline \hline Model & $b$ & $\gamma$ & $\psi$ & $\begin{array}{c}\text { Voluntary } \\
\text { annuity market } \\
\text { participation }\end{array}$ & $\begin{array}{c}\text { Voluntary } \\
\text { annuity } \\
\text { demand }\end{array}$ & $\begin{array}{c}\text { Share } \\
\text { of wealth } \\
\text { annuitized }\end{array}$ \\
\hline Estimates & 0.20 & 1.53 & 0.47 & 4.25 & 3.95 & 20.37 \\
s.e. & 0.00001 & 0.0003 & 0.0003 & & & \\
Data & & & & 3.19 & 1.65 & 36.61 \\
s.d. & & & & 17.57 & 4.57 & 31.57 \\
\hline
\end{tabular}

B. Stockholders

\begin{tabular}{ccccccc}
\hline \hline Model & $b$ & $\gamma$ & $\psi$ & $\begin{array}{c}\text { Voluntary } \\
\text { annuity market } \\
\text { participation }\end{array}$ & $\begin{array}{c}\text { Voluntary } \\
\text { annuity } \\
\text { demand }\end{array}$ & $\begin{array}{c}\text { Share } \\
\text { of wealth } \\
\text { annuitized }\end{array}$ \\
\hline Estimates & 0.10 & 2.20 & 0.59 & 10.40 & 5.30 & 24.00 \\
s.e. & 0.0001 & 0.002 & 0.003 & & & \\
Data & & & & 9.59 & 3.66 & 26.27 \\
s.d. & & & & 29.45 & 9.58 & 25.77 \\
\hline
\end{tabular}

Notes to Table 6: Panel A reports estimated parameters for non-stockholder model using a method of simulated moments to pick the structural parameters that minimize the distance between some selected moments in the data and in the model. The moments are the participation in the annuity market, and, conditional on participation, the amount of annuity demand at retirement and the share of wealth annuitized. Panel B reports the same estimates for the model that allows stock market participation. Standard errors are computed using an optimal weighting matrix that is based on the inverse of the variance of the empirical moments. 
Table 7: Annuity market participation, average annuity demand, share of wealth annuitized and wealth equivalence measure.

A. Non-stockholders

\begin{tabular}{ccccc}
\hline \hline Model & $\begin{array}{c}\text { Voluntary } \\
\text { annuity market } \\
\text { participation }\end{array}$ & $\begin{array}{c}\text { Voluntary } \\
\text { annuity } \\
\text { demand }\end{array}$ & $\begin{array}{c}\text { Share } \\
\text { of wealth } \\
\text { annuitized }\end{array}$ & $\begin{array}{c}\text { Annuity } \\
\text { equivalent } \\
\text { wealth }\end{array}$ \\
\hline Data & 3.19 & 1.65 & 36.61 & - \\
MSM & 4.25 & 3.95 & 20.37 & 99.88 \\
Low Pension & 4.99 & 4.81 & 26.86 & 99.85 \\
High Pension & 3.25 & 3.00 & 14.36 & 99.89 \\
Low Survival & 0.00 & 0.00 & 0.00 & 100.0 \\
Actuarial Fair & 15.25 & 4.76 & 37.31 & 99.46 \\
\hline
\end{tabular}

B. Stockholders

\begin{tabular}{ccccc}
\hline \hline Model & $\begin{array}{c}\text { Voluntary } \\
\text { annuity market } \\
\text { participation }\end{array}$ & $\begin{array}{c}\text { Voluntary } \\
\text { annuity } \\
\text { demand }\end{array}$ & $\begin{array}{c}\text { Share } \\
\text { of wealth } \\
\text { annuitized }\end{array}$ & $\begin{array}{c}\text { Annuity } \\
\text { equivalent } \\
\text { wealth }\end{array}$ \\
\hline Data & 9.59 & 3.66 & 26.27 & - \\
\hline MSM & 10.40 & 5.30 & 24.04 & 99.89 \\
Low Pension & 18.10 & 7.55 & 37.75 & 99.50 \\
High Pension & 8.25 & 4.23 & 18.36 & 99.98 \\
Low Survival & 2.45 & 0.16 & 0.62 & 99.89 \\
Actuarial Fair & 31.05 & 18.01 & 96.58 & 98.81 \\
\hline
\end{tabular}

Notes to Table 7: Panel A reports simulated results using the non-stockholder model, and Panel B the simulated results using stock market participants. The risk free rate is set to $2 \%$, the equity premium at $4 \%$ and the standard deviation of risky asset return at $18 \%$. Pre-existing pension income is set at each group's median value. Comparative statics are performed over several parameter specifications. In particular, for the MSM parameters are set equal to estimated parameters reported in Table 6, in Low and High Pension cases the corresponding 25th and 75th percentiles of pre-existing pension are used for each group. Low survival is the case where individual's survival probabilities are reduced by $10 \%$ and Actuarial Fair is the case for annuities with zero load factor. Voluntary annuity market participation reports average participation in percentage terms, Voluntary annuity demand is defined as average annual annuity income in thousands of pounds, conditional on participation, and the voluntary share of wealth annuitized is the optimal amount of purchased annuity at retirement as a percentage of total financial wealth at retirement. The Annuity equivalent wealth reports average AEW, which is defined as the wealth each individual is willing to give up in order to e able to access the annuity market. 


\section{Figures}

Figure 1: Wealth distribution, annuity market participation and annual pension income over the wealth distribution

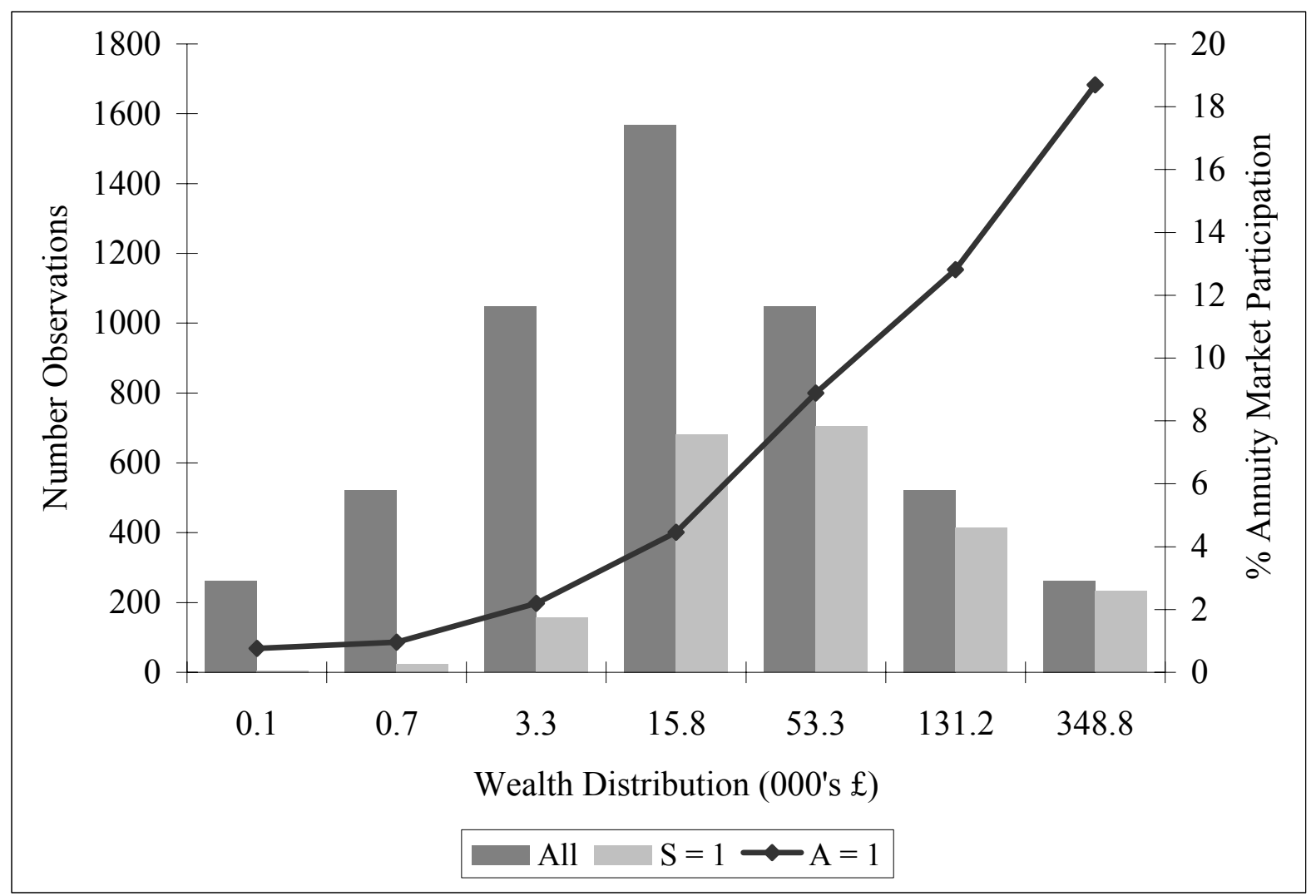

Notes to Figure 1: The columns show the number of households (measured on the ordinate on the left hand side) around the $2.5 \%, 10 \%, 25 \%, 50 \%, 75 \%, 90 \%$ and $97.5 \%$ percentiles of the wealth distribution in the whole sample ("All") and the sub-sample consisting of stock market participants ("S $=1$ "). The figure shows on the ordinate on the right hand side the average percentage of households participating in the voluntary annuity market ("A = 1") among the households located around a certain quantile of the wealth distribution. The sample consists of 5,233 retired households from the first (2002) wave of the English Longitudinal Study of Ageing (ELSA). 
Figure 2: Decomposition of annual pension income into public and private sector pension income and annual annuity income over the wealth distribution

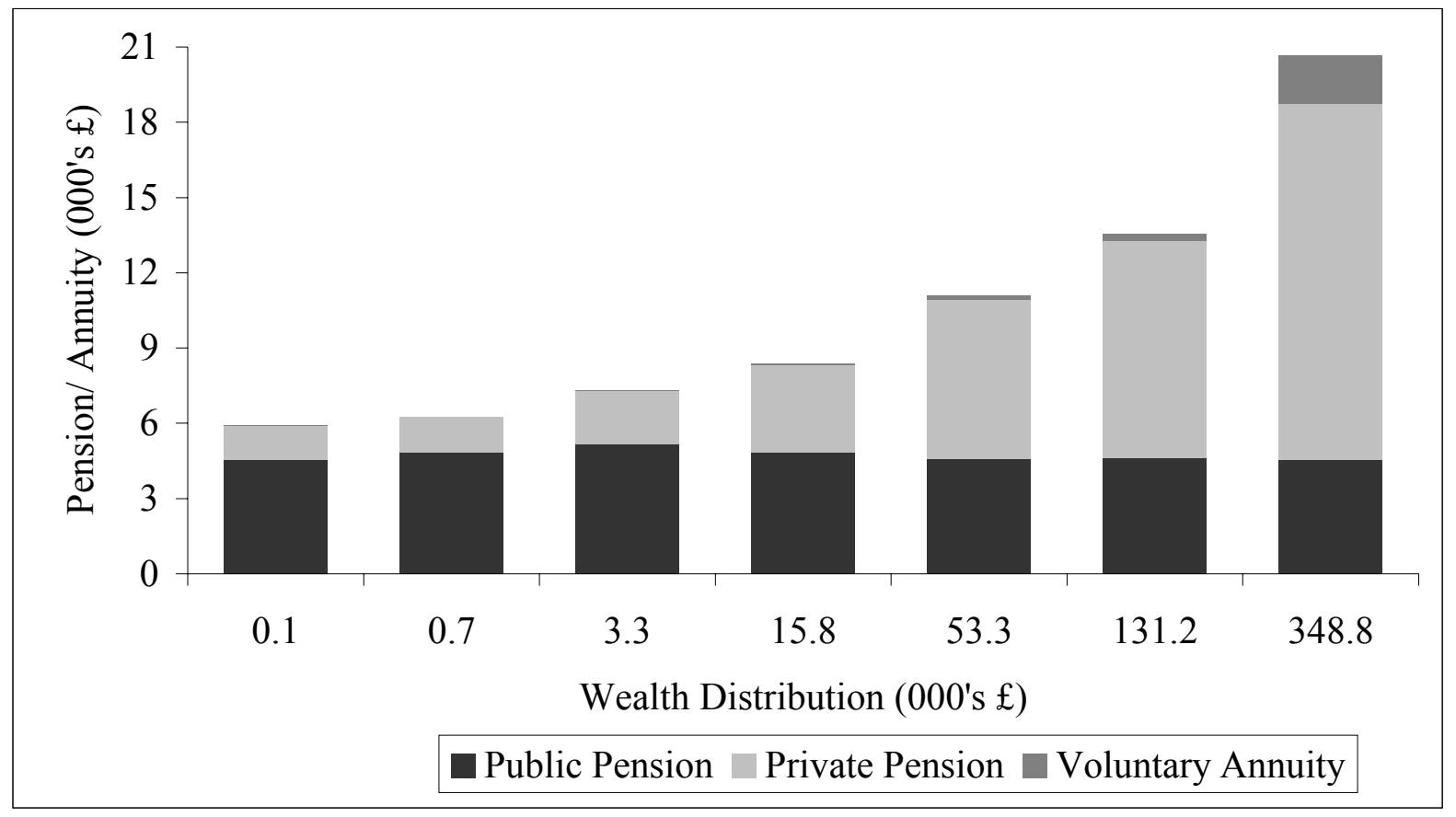

Notes to Figure 2: The figure decomposes the average total annual pension income of households around a certain quantile of the wealth distribution into income from public pensions, private (individual or occupational) pensions (excluding voluntary annuities) and voluntary annuitization. The wealth distribution is generated to represent from the left to the right $5 \%, 10 \%, 20 \%, 30 \%, 20 \%, 10 \%, 5 \%$ of the observations. Correspondingly, the abscissa shows the $2.5 \%, 10 \%, 25 \%, 50 \%, 75 \%, 90 \%$ and $97.5 \%$ percentiles of the wealth distribution. The sample consists of 5,233 retired households from the first (2002) wave of the English Longitudinal Study of Ageing (ELSA). 
Figure 3: Percentage point deviations between subjective and gender-specific objective survival probability by subjective health condition

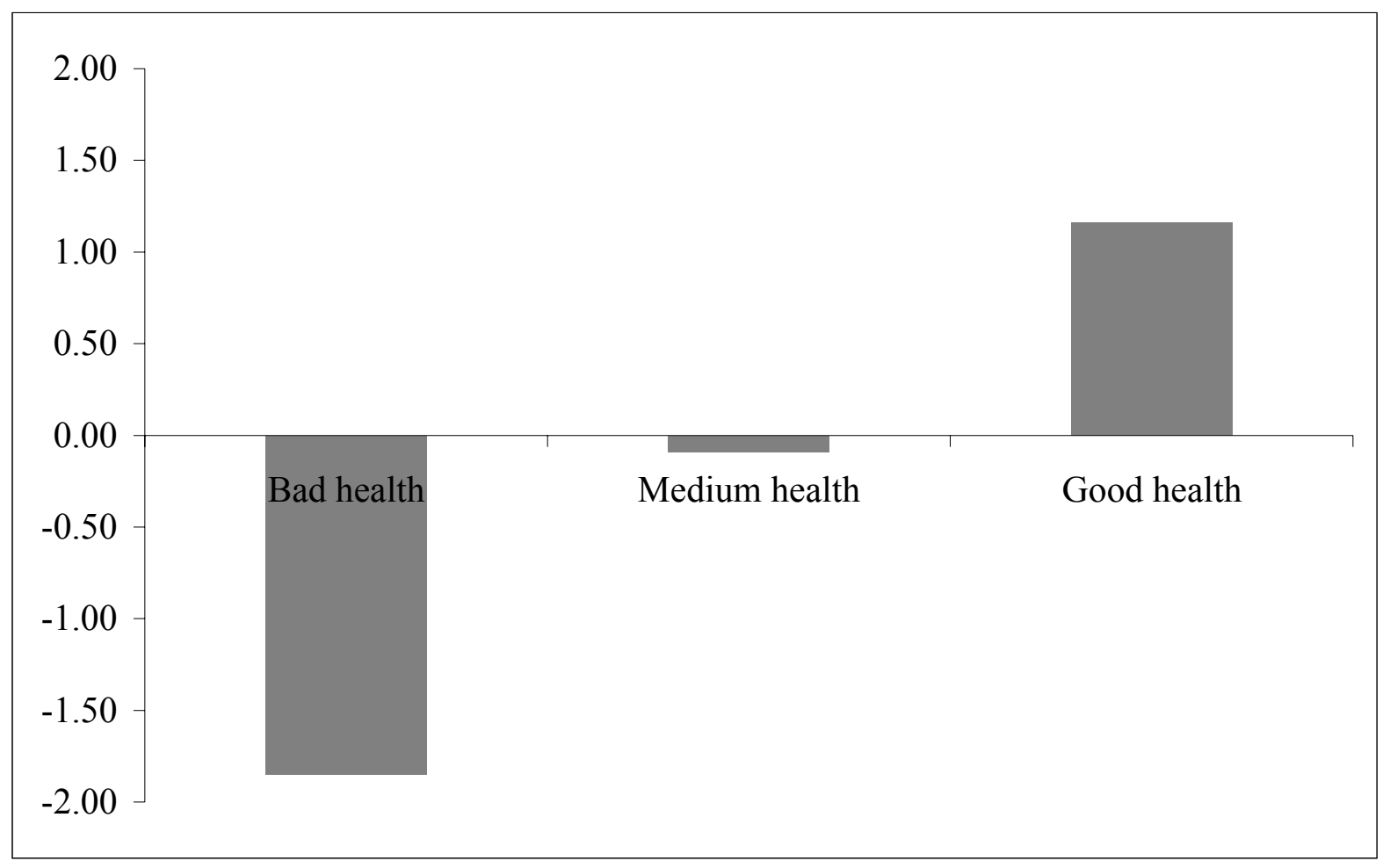

Notes to Figure 3: The figure shows the average percentage point deviation between the self-reported subjective probability to survive up to a certain (age-specific) age and the gender-specific "objective" survival probability for the sub-samples of households in bad, medium or good health condition. The objective survival probability is calculated from the "Interim Life Tables" produced by the Government Actuary's Department (GAD) using data for the years 2002-2004. The sample consists of 5,233 retired households from the first (2002) wave of the English Longitudinal Study of Ageing (ELSA). 
Figure 4: Annuity demand as a function of wealth at retirement

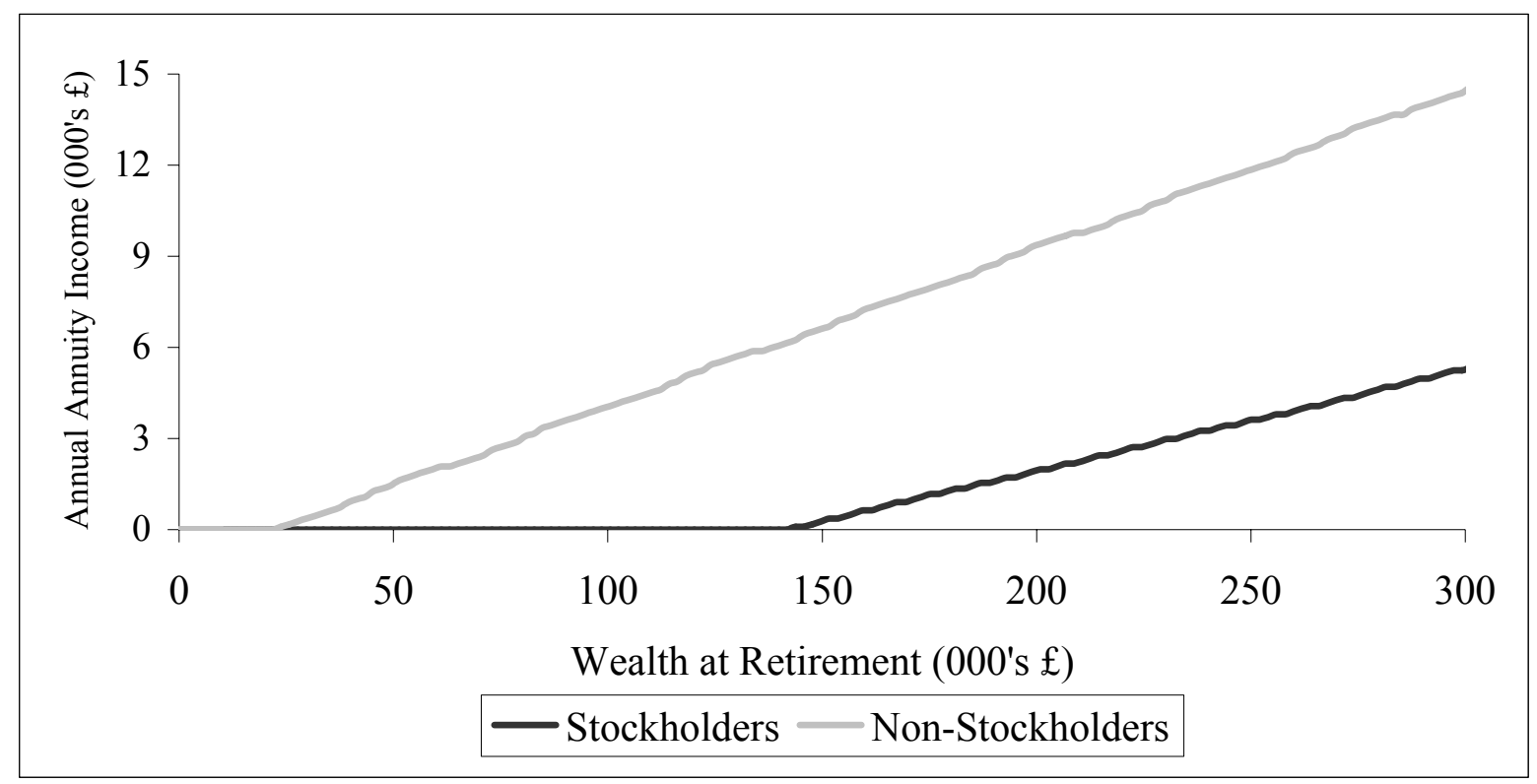

Notes to Figure 4: This figure shows the policy function for annuity demand as a function of wealth at retirement for stock market participants (Stockholders) and non-participants (Non-stockholders).

Figure 5: Average consumption profiles

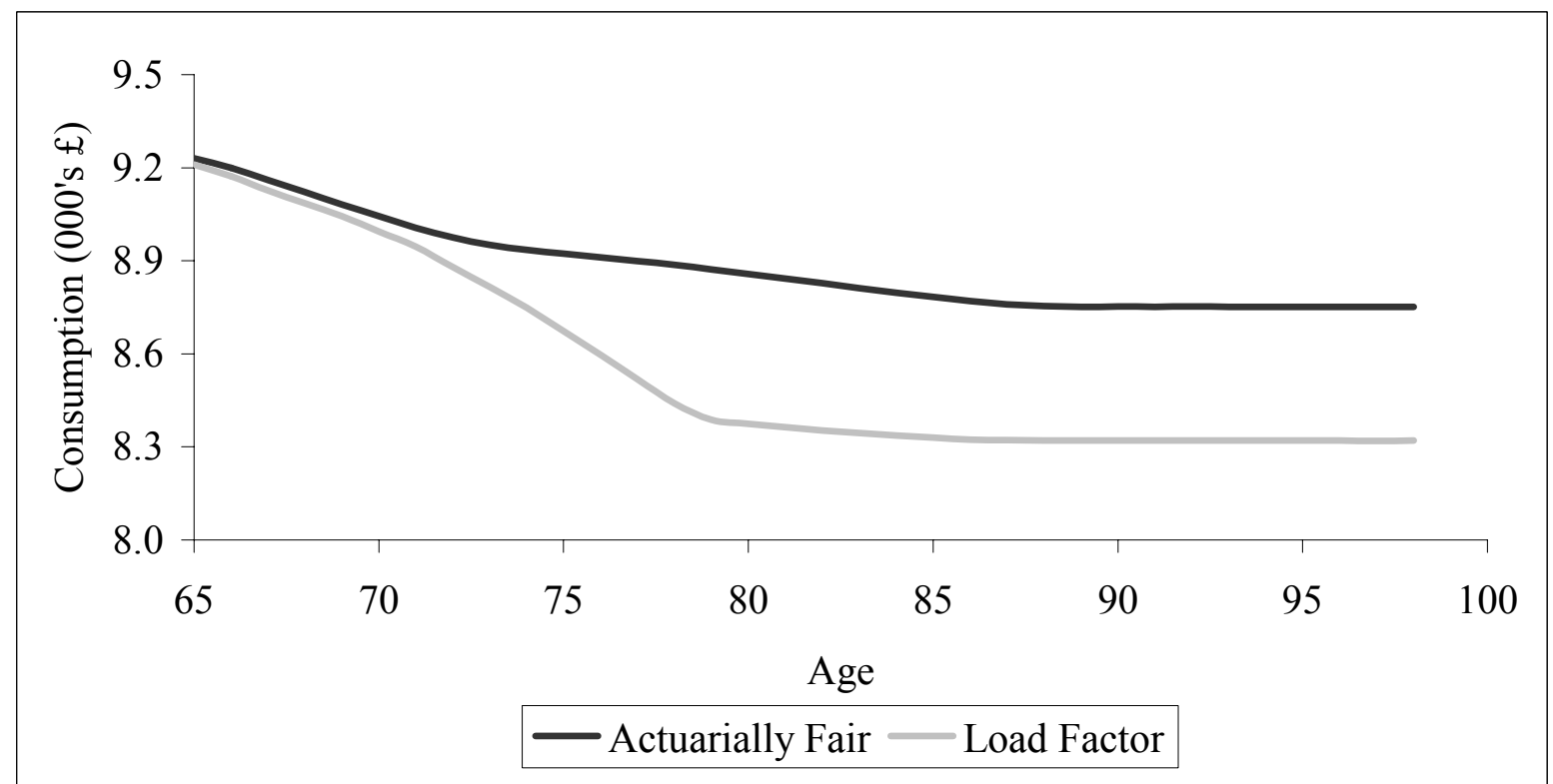

Notes to Figure 5: Actuarially Fair represents consumption for the model with access to actuarially fair annuities. Load factor represents consumption for the model with annuities subject to a load factor of $20 \%$. 